\title{
Antidepressant Drug-Induced Hypothalamic Cooling in Syrian Hamsters
}

\author{
Wallace C. Duncan, Jr., Ph.D., Kimberly A. Johnson, B.A., and Thomas A. Wehr, M.D.
}

Antidepressant drugs have been reported to alter the circadian pattern of body temperature, but specific effects on the amplitude or on average body temperature are not consistent, and there have been no specific studies to examine chronic drug effects on brain temperature. To address these issues, hypothalamic temperature $\left(T_{h y}\right)$ was monitored telemetrically in hamsters treated with three antidepressant drugs: the monoamine oxidase inhibitor (MAOI), clorgyline; the 5HT reuptake inhibitor, fluoxetine; and the alkali metal, lithium. For comparison, hamsters were also treated with two neuroleptic drugs, chlorpromazine and haloperidol. Each of the three antidepressant drugs, but neither of the neuroleptic drugs, produced a chronic decrease in diurnal (rest-phase) hypothalamic temperature. The $T_{\text {hy-decreasing effect of }}$ clorgyline was not prevented by pinealectomy, and $T_{h y}$ decreased more than peritoneal temperature $\left(T_{p}\right)$, thus reducing the temperature difference between the hypothalamus and the peritoneal cavity. Less general effects of the antidepressants were also observed. Clorgyline and fluoxetine, but not lithium, delayed the 24-hour rhythm of $T_{h y}$. Clorgyline and lithium, but not fluoxetine decreased the average 24-hour $T_{h y}$. The neuroleptics chlorpromazine and haloperidol decreased the amplitude of the 24-hour $T_{\text {hy }}$ rhythm. The fact that chronic antidepressant drugs, but not neuroleptic drugs, decrease $T_{h y}$ is consistent with their different neurotransmitter effects and clinical applications, and raises the possibility that their antidepressant property might be related to their capacity to decrease $T_{h y}$ during sleep. [Neuropsychopharmacology 12:17-37, 1995]
KEY WORDS: Body temperature; Hypothalamus; Circadian rhythm; Depression; Serotonin; Antidepressant drugs

Primary depression is often characterized by abnormalities in the circadian phase, amplitude, and/or body temperature level $\left(\mathrm{T}_{\mathrm{b}}\right)$ (Tupin 1970; Mellerup et al. 1978; Pflug et al. 1981; Avery et al. 1982; Beersma et al. 1983; Lund et al. 1983; Schulz and Lund 1983; van den Hoofdakker and Beersma 1985; Avery et al. 1986; Goetze and Tolle 1987; Elsenga and Van den Hoofdakker 1988; Souetre et al. 1988), which are sometimes reversed in remission (Pflug et al. 1981; Avery et al.

From the Clinical Psychobiology Branch, NIMH, NIH, Bethesda, Maryland.

Address correspondence to: Wallace C. Duncan, Jr., Ph.D., Room 4S-239, Building 10, NIMH, Bethesda, Maryland 20892.

Received November 8, 1993; revised June 21, 1994; accepted July 2, 1994
1986; Lund 1987; Souetre et al. 1988). These observations suggest that impaired regulation of the circadian variation in $\mathrm{T}_{b}$ is part of the pathophysiology of depression.

Pharmacological and nonpharmacological treatments of depression restore a more normal daily pattern of $\mathrm{T}_{b}$ in patients with these abnormalities. For example, tricyclic antidepressant drugs (Souetre et al. 1988), lithium (Mellerup et al. 1978; Lund 1987), electroconvulsive therapy (Avery et al. 1986), and bright light (Rosenthal et al. 1990) are reported to either increase the circadian amplitude of $\mathrm{T}_{\mathrm{b}}$, and/or to decrease average $T_{b}$ during sleep. Chronic antidepressant drug treatment (Fernstrom et al. 1985), bright light treatment (Gaist et al. 1990), and sleep deprivation therapy (Wu et al. 1991) have also been reported to decrease total or regional brain glucose utilization in humans. The fact that a variety of pharmacological and nonpharmacological treatments tend to restore a more normal 
circadian pattern of $T_{b}$ suggests that daily variation in $\mathrm{T}_{\mathrm{b}}$ is an important correlate of clinical antidepressant response.

Relatively few animal studies have examined chronic effects of antidepressant treatments on $\mathrm{T}_{\mathrm{b}}$. Most have focused on acute effects (Clark and Clark 1980; Clark and Lipton 1986). Brown and Seggie (1988) observed a decrease in radiotelemetry-monitored peritoneal temperature $\left(T_{p}\right)$ during chronic treatment of rats with desipramine (DMI). Our group (Gao et al. 1991) observed a decrease in radiotelemetry-monitored $\mathrm{T}_{\mathrm{p}}$ in Syrian hamsters chronically treated with the monoamine oxidase inhibitor (MAOI) and clorgyline, and a decrease in $\mathrm{T}_{\text {hy }}$ was observed during treatment with the selective $5 \mathrm{HT}$ reuptake inhibitor fluoxetine (Gao et al. 1992). Others have reported that chronic DMI treatment decreased glucose utilization in the rat brain (Gerber et al. 1983), and chronic electroconvulsive stimulation decreased rectal temperature in mice (Gleiter et al. 1989). The results of these studies suggest that chronic antidepressant treatments may chronically alter $\mathrm{T}_{\mathrm{b}}$.

In the current experiments, effects of chronic treatment with antidepressant and neuroleptic drugs on brain temperature are examined within the hypothalamus, the location of a central thermostat that controls a variety of themoregulatory functions. To reduce the effects of stress on thermoregulatory physiology (Berkey et al. 1990), we used radiotelemetry techniques to measure temperature in freely moving animals. We specifically investigated whether antidepressant and neuroleptic drug treatments alter the amplitude, phase, or level of hypothalamic temperature $\left(\mathrm{T}_{\text {hy }}\right)$, as would be predicted on the basis of results of previous studies (Mellerup et al. 1978; Avery et al. 1986; Lund 1987; Souetre et al. 1988; Rosenthal et al. 1990).

\section{METHODS}

\section{Animals and Procedures}

Male golden hamsters (Mesocricetus auratus, LGV: lak, Charles River), 12 weeks to 16 weeks old weighing approximately 140 grams, were used in all studies. Prior to surgery, animals were group-housed in LD 14:10 with access to food and water ad libitum. Transmitters (Model XM-FH, Mini-Mitter, Inc.) for recording hypothalamic temperature (resolution $=0.02^{\circ} \mathrm{C}$ ) were implanted using dental cement. Temperature-sensitive probes were positioned with their tips $(\approx 460 \mu$ diameter $)$ in the hypothalamus using the following stereotaxic coordinates (with bregma and lambda in the same horizontal plane) $: 0.25 \mathrm{~mm}$ posterior to bregma, $1.8 \mathrm{~mm}$ lateral to midline, and $7.3 \mathrm{~mm}$ below the skull. In selected hamsters, immediately following hypothalamic probe surgery, transmitters (Model TM-Disc, Mini-
Mitter, Inc.) were implanted in order to concurrently record peritoneal temperature (resolution $=0.02^{\circ} \mathrm{C}$ ). These transmitters were located between the ileum and the abdominal wall. Surgical procedures for transmitter implants and pinealectomy were conducted under sodium pentobarbital anaesthesia $(90 \mathrm{mg} / \mathrm{kg}$, IP). Identity of extracted pineals was verified histologically.

After surgery, hamsters were individually housed in ventilated and sound-attenuated chambers (Napco Model 3810) with free access to food and water. Animals were maintained under LD 14:10 (L: 0100-1500 hours, D: $1500-0100$ hours) or in constant darkness (DD) in an ambient temperature of $22 \pm 1^{\circ} \mathrm{C}$. Light intensity within the chamber was $10 \mu \mathrm{W}$ to $20 \mu \mathrm{W} \mathrm{cm} \mathrm{cm}^{-2}$. Hamsters were allowed at least 7 days to recover from surgery, and recovery was judged to have occurred when the rhythm stabilized.

Hamsters received clorgyline $(2 \mathrm{mg} / \mathrm{kg} / \mathrm{d}$; administered SC via mini osmotic pumps (Alzet Model 2002), fluoxetine (Eli Lilly and Company; 2, 10, or 20 $\mathrm{mg} / \mathrm{kg} / \mathrm{d}$; administered in a liquid diet, lithium $(0.075 \%$ to $0.45 \%$, administered in chow), chlorpromazine (Innovative Research of America; implanted SC as a 3-week, $25 \mathrm{mg}$ pellet), or haloperidol (Haldol Deconoate 100, McNeil Pharmaceutical; administered IM; or implanted SC as a 3-week, $25 \mathrm{mg}$ haloperidol pellet; Innovative Research of America). In these experiments, different routes of drug delivery were used in order to achieve appropriate clinical doses whereby minimizing stress to the animals. During fluoxetine treatment, the caloric intake of fluoxetine-treated hamsters was yoked to that of a control group. Consumption was monitored daily and little evidence of spillage was observed. In the course of the experiment, orbital blood samples were taken from anesthetized hamsters to obtain measurements of plasma lithium or fluoxetine levels. At the end of the experiment, blood samples were collected by cardiac puncture to obtain measurements of plasma chlorpromazine or haloperidol levels. At the end of the experiment, the animals were sacrificed and their brains rapidly frozen on dry ice, cut into $30 \mu \mathrm{m}$ sections, and examined for placements of transmitter probes. All probe tips were verified to have been in the hypothalamus. Following the experiment, transmitters were recalibrated and found to be consistent with presurgery calibration levels.

\section{Data Collection and Analysis}

$\mathrm{T}_{\text {hy }}\left({ }^{\circ} \mathrm{C}\right)$ was recorded telemetrically every 5 minutes, and data were stored on a laboratory computer. Twenty-four hour waveforms were analyzed after reducing data to 15 minute averages. Chronic drug effects were visually examined and plotted for each animal after calculating 2-hour averages. Between 5 days and 7 days of continuously monitoring, temperatures were se- 
lected to represent baseline (BL), subchronic (WEEK 1), and chronic (WEEKS 2 to 7) treatment phases. During BL and during each of the treatment weeks, data were averaged over the 14-hour light period $\left(\mathrm{T}_{\text {hy }}-\mathrm{L}\right)$, the 10hour dark period $\left(T_{\text {hy }}-D\right)$, and the total 24 -hour period

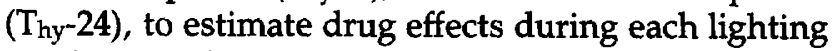
condition and during the entire day. The 24-hour range in $T_{\text {hy }}$ was estimated as the difference between the light phase minimum ( $\mathrm{T}_{\text {hy }}-\mathrm{L} \mathrm{min}$ ) and the dark phase maximum ( $\mathrm{T}_{\text {hy }}$-D max) during the weekly drug treatment intervals. Cosinor analysis was used to estimate the acrophase and the amplitude of the 24-hour rhythm in brain and peritoneal temperature (Teicher and Barmer 1990).

Two-way ANOVA with repeated measures (TRT $x$ WEEK) was used to analyze the interaction between drug treatment and the week of treatment. Two-way ANOVA with repeated measures (WEEK of treatment $\times$ PROBE location) was used to analyze chronic effects of drugs on $T_{h y}$ and $T_{p}$. The GreenhouseGeisser approximation was used in the ANOVA to correct for the lack of homogeneity in the correlated data. (Full degrees of freedom are reported). To further explore statistically significant ANOVA results, paired $t$-tests and independent group $t$-tests, uncorrected for multiple comparisons, were used. Paired $t$-tests were used to assess differences between baseline and drug treatments whereas independent group $t$-tests were used to assess differences between drug treatments and control treatments.

\section{RESULTS OF CHRONIC ANTIDEPRESSANT DRUG TREATMENT EFFECTS ON BODY TEMPERATURE}

\section{Clorgyline}

The effects of chronic treatment with clorgyline on body temperature $\left(T_{h y}\right.$ and/or $\left.T_{p}\right)$ were examined in three separate experiments. The results of these experiments are shown in Figures 1, 2, 3, 4, and 7, and Tables 1 and 2.

\section{Experiment One: CLG's Effects on Hypothalamic Tem-} perature in LD 14:10-Housed Hamsters. In the first experiment, we examined the effects of 4 weeks of CLG treatment on $T_{\text {hy }}$ in hamsters house in LD 14:10 (Table 1, Figure 1). The level of $\mathrm{T}_{\text {hy }}$ exhibited a 24-hour variation over the course of 5 weeks. Peak levels occurred during the dark phase and minimum levels occurred during the light phase, as we have previously described (Figure 7) (Duncan et al. 1990; Gao et al. 1991; Gao et al. 1992). During the first week of treatment, clorgyline decreased $T_{\text {hy }}$. During the second week, peak $T_{\text {hy }}$ gradually increased toward the baseline and then remained near baseline levels during the third and fourth weeks. In contrast, during the second, third, and fourth weeks of treatment, minimum $T_{\text {hy }}$ showed little recovery toward the baseline. Two factor (CLG, SAL) ANOVA with repeated measures (BL, WEEK 1, WEEK 3) was used to determine the drug effects on $T_{\text {hy }}$ during the 24-hour period ( $\mathrm{T}_{\text {hy-24), }}$, and during the light $\left(\mathrm{T}_{\text {hy }}-\mathrm{L}\right)$, and dark periods $\left(\mathrm{T}_{\mathrm{hy}}-\mathrm{D}\right)$. In saline-treated

Table 1. Mean and Repeated Measures Analysis of Variance (ANOVA) Summary of Clorgyline $(n=5)$ and Saline $(n=7)$ Treatment Effects on Hypothalamic Temperature (Th) during Baseline, Week 1 and Week 3

\begin{tabular}{|c|c|c|c|c|c|c|c|c|c|}
\hline \multirow[b]{2}{*}{ Treatment } & \multirow[b]{2}{*}{ Week } & \multicolumn{4}{|c|}{ 24-Hour } & \multicolumn{2}{|c|}{ Light Phase } & \multicolumn{2}{|c|}{ Dark Phase } \\
\hline & & Th-24 & Range & Acrophase & Amplitude & Th-L & Th-L Min & Th-D & Th-D Max \\
\hline \multirow[t]{3}{*}{ Clorgyline } & Baseline & $\begin{array}{c}37.43^{a} \\
0.11\end{array}$ & $\begin{array}{l}1.91 \\
0.11\end{array}$ & $\begin{array}{c}17: 31^{b} \\
0: 22\end{array}$ & $\begin{array}{l}0.51 \\
0.07\end{array}$ & $\begin{array}{r}37.18 \\
0.11\end{array}$ & $\begin{array}{r}36.76 \\
0.13\end{array}$ & $\begin{array}{r}37.82 \\
0.11\end{array}$ & $\begin{array}{r}38.68 \\
0.15\end{array}$ \\
\hline & Week 1 & $\begin{array}{c}36.9 \\
0.13\end{array}$ & $\begin{array}{l}2.20 \\
0.28\end{array}$ & $\begin{array}{r}19: 51 \\
0: 18\end{array}$ & $\begin{array}{l}0.50 \\
0.17\end{array}$ & $\begin{array}{r}36.58 \\
0.12\end{array}$ & $\begin{array}{r}36.06 \\
0.15\end{array}$ & $\begin{array}{r}37.31 \\
0.27\end{array}$ & $\begin{array}{r}38.26 \\
0.37\end{array}$ \\
\hline & Week 3 & $\begin{array}{r}37.13 \\
0.15\end{array}$ & $\begin{array}{l}2.37 \\
0.14\end{array}$ & $\begin{array}{r}19: 00 \\
0: 28\end{array}$ & $\begin{array}{l}0.59 \\
0.15\end{array}$ & $\begin{array}{r}36.75 \\
0.12\end{array}$ & $\begin{array}{c}36.38 \\
0.1\end{array}$ & $\begin{array}{r}37.64 \\
0.28\end{array}$ & $\begin{array}{r}38.75 \\
0.23\end{array}$ \\
\hline \multirow[t]{3}{*}{ Saline } & Baseline & $\begin{array}{r}37.61 \\
0.55\end{array}$ & $\begin{array}{l}1.73 \\
0.19\end{array}$ & $\begin{array}{r}17: 44 \\
0: 54\end{array}$ & $\begin{array}{l}0.48 \\
0.08\end{array}$ & $\begin{array}{r}37.38 \\
0.58\end{array}$ & $\begin{array}{c}36.96 \\
0.5\end{array}$ & $\begin{array}{r}37.96 \\
0.51\end{array}$ & $\begin{array}{r}38.69 \\
0.66\end{array}$ \\
\hline & Week 1 & $\begin{array}{r}37.64 \\
0.54\end{array}$ & $\begin{array}{l}1.92 \\
0.23\end{array}$ & $\begin{array}{r}18: 05 \\
0: 44\end{array}$ & $\begin{array}{l}0.50 \\
0.10\end{array}$ & $\begin{array}{r}37.38 \\
0.57\end{array}$ & $\begin{array}{l}37 \\
0.58\end{array}$ & $\begin{array}{r}38.02 \\
0.50\end{array}$ & $\begin{array}{r}38.92 \\
0.48\end{array}$ \\
\hline & Week 3 & $\begin{array}{r}37.59 \\
0.55\end{array}$ & $\begin{array}{l}2.04 \\
0.31\end{array}$ & $\begin{array}{r}17: 38 \\
0: 38\end{array}$ & $\begin{array}{l}0.53 \\
0.05\end{array}$ & $\begin{array}{r}37.32 \\
0.57\end{array}$ & $\begin{array}{r}36.87 \\
0.58\end{array}$ & $\begin{array}{r}38.00 \\
0.53\end{array}$ & $\begin{array}{r}38.91 \\
0.53\end{array}$ \\
\hline \multicolumn{10}{|c|}{$\begin{array}{l}\text { ANOVA results } \\
\text { Treatment } \times \text { week }\end{array}$} \\
\hline $\begin{array}{l}\text { F } \\
d f \\
p<\end{array}$ & & $\begin{array}{c}35.2 \\
2,20 \\
0.001\end{array}$ & $\begin{array}{l}0.54 \\
2,20 \\
\text { NS }\end{array}$ & $\begin{array}{c}26.70 \\
2,20 \\
0.001\end{array}$ & $\begin{array}{l}0.47 \\
2,20 \\
\text { NS }\end{array}$ & $\begin{array}{c}45.9 \\
2,20 \\
0.001\end{array}$ & $\begin{array}{c}38.6 \\
2,20 \\
0.001\end{array}$ & $\begin{array}{l}14.20 \\
2,20 \\
0.01\end{array}$ & $\begin{array}{l}10.30 \\
2,20 \\
0.01\end{array}$ \\
\hline
\end{tabular}

${ }^{a}{ }^{\circ} \mathrm{C}$, Mean $\pm \mathrm{SD}$.

${ }^{b} \mathrm{HH}: \mathrm{MM}, \mathrm{Cean} \pm \mathrm{SD}$. 

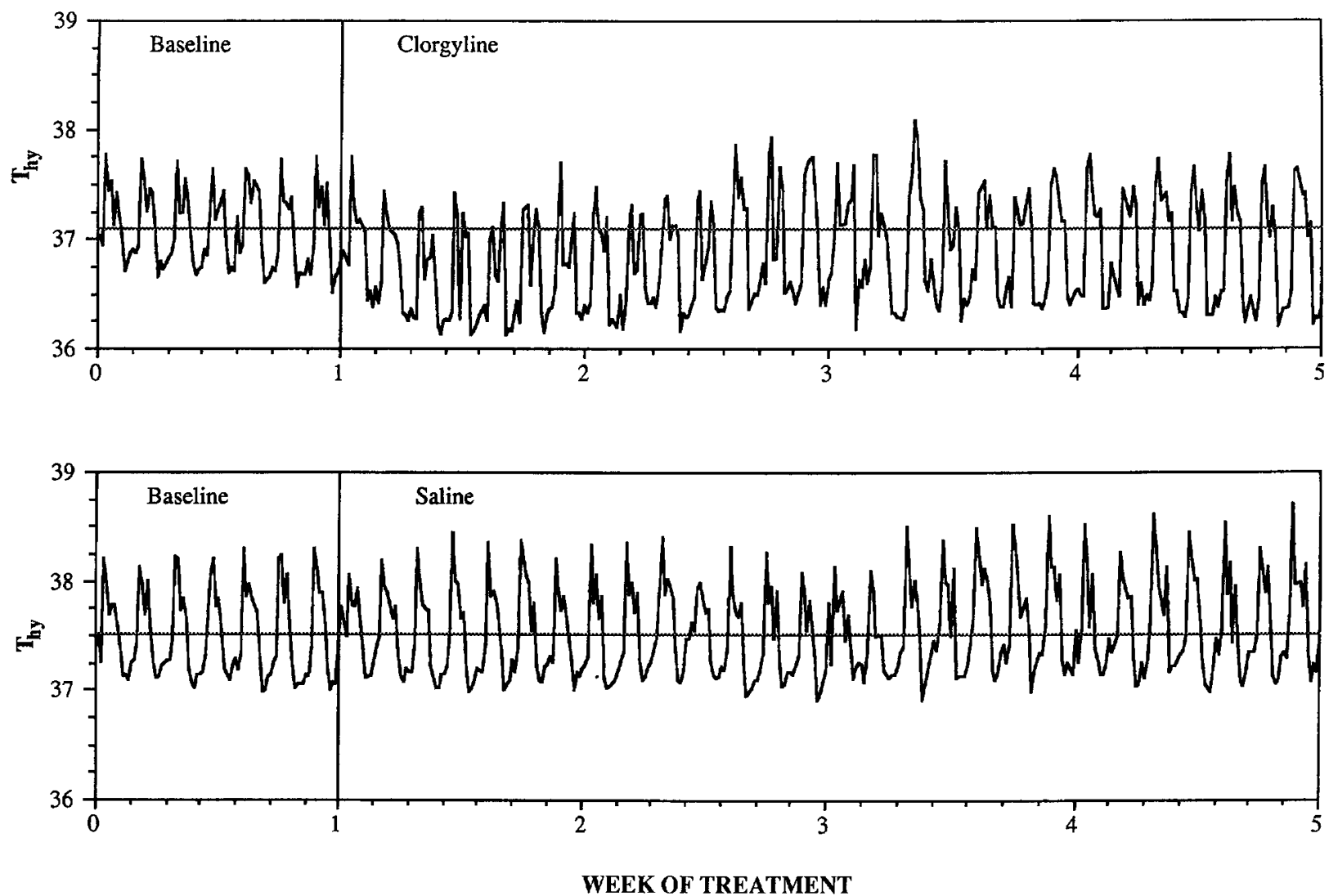

Figure 1. The mean hypothalamic temperature of five clorgyline-treated (top) and seven saline-treated (bottom) hamsters during baseline and 4 weeks of treatment. The horizontal line corresponds to the average 24-hour brain temperature during the baseline interval.

hamsters, $T_{\text {hy }}$ did not change during the 4 weeks of treatment. Significant interactions were found between drug treatment (CLG, SAL) and week of treatment (BL, WEEK 1, WEEK 3) for $\mathrm{T}_{\text {hy }}-24, \mathrm{~T}_{\text {hy }}-\mathrm{L}$, and $\mathrm{T}_{\text {hy }}-\mathrm{D}$ (Table 1). Two-factor ANOVA of cosinor-estimated phase indicated a significant interaction between drug and week. Compared with saline-treatment, clorgylinetreatment decreased $\mathrm{T}_{\text {hy }} 24$ during WEEK 1 , decreased $\mathrm{T}_{\text {hy- }} \mathrm{D}$ during WEEK 1 , and decreased $\mathrm{T}_{\text {hy }} \mathrm{L}$ during WEEK 1 and WEEK 3 (Table 7). Further analysis of the cosinor results indicated that, compared with SAL, CLG delayed the phase of $T_{\text {hy }}$ during WEEK 1 and WEEK 3.

Experiment Two: CLG's Effects on Concurrently Measured Hypothalamic and Peritoneal Temperature in LD 14:10-Housed Hamsters. In the second CLG experiment, hamsters housed in LD 14:10 were treated with CLG $(n=6)$ for 3 weeks, and treatment effects on concurrent measures of $T_{\text {hy }}$ and $T_{p}$ were examined. $T_{\text {hy }}$ and $T_{p}$ decreased during all 3 weeks of CLG treatment

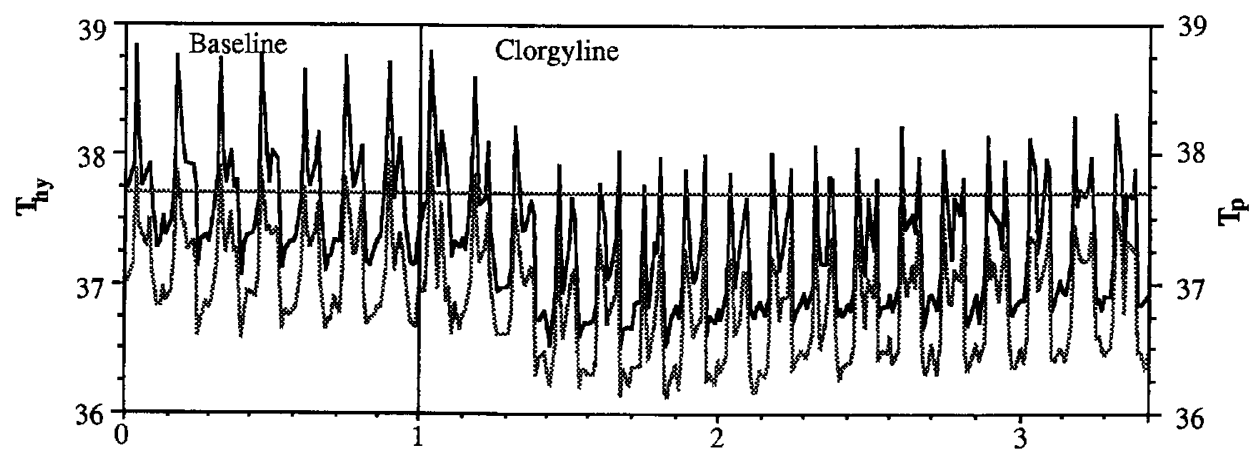

WEEK OF TREATMENT
Figure 2. The mean brain ( $\mathrm{T}_{\text {hy }}$ ) and peritoneal temperatures $\left(\mathrm{T}_{\mathrm{p}}\right)$ recorded simultaneously from six clorgylinetreated hamsters over the course of 24 days. The lower temperature corresponds to the peritoneal temperature. The first week corresponds to baseline. Clorgyline treatment began on day 7 . 
(Figure 2). $T_{\text {hy }}$ and $T_{p}$ decreased the most during the first week of CLG treatment. $T_{\text {hy }}$ and $T_{p}$ increased gradually toward baseline levels during the second week of treatment, but full recovery of $T_{\text {hy }}$ and $T_{p}$ to baseline levels had not developed during the third week of chronic treatment.

Analysis of CLG's effects on concurrently measured $T_{\text {hy }}$ and $T_{p}$ was conducted using a two-factor repeated measures ANOVA with WEEK of treatment (B1, WEEK 1 , WEEK 2) as one within-subject factor and temperature PROBE $\left(T_{\text {hy }}, T_{p}\right)$ as another within-subject factor. Statistically significant effects were found for all variables except 24-hour range and amplitude. The interaction between WEEK and PROBE was significant for the dependent variables T-24, and T-L. Further, there were significant effects of WEEK on acrophase, T-Lmin, $T-D$, and T-Dmax, as well as significant effects of PROBE for acrophase, T-D, and T-max (Table 2). Chronic treatment with clorgyline diminished the diurnal temperature difference between hypothalamus and peritoneum (Figure 3).

The relationship between $T_{\text {hy }}$ and $T_{p}$ was also examined by calculating the linear regression of $T_{\text {hy }}$ on
$T_{p}$ for each animal (for representative case see Figure 4). Clorgyline treatment decreased $T_{p}$ and $T_{\text {hy }}$ relative to baseline, but the slopes of the regression between $\mathrm{T}_{\mathrm{p}}$ and $\mathrm{T}_{\text {hy }}$ did not substantially change; thus, the regression provided no evidence for selective depression of $T_{h y}$ at elevated $T_{p}$ during either baseline, or during clorgyline treatment, as would be indicated by a slope less than 1.0.

\section{Experiment Three: Clorgyline's Effects on Hypothalamic} Temperature in Pinealectomized Hamsters. $\mathrm{T}_{\mathrm{hy}}$ decreased in both clorgyline-treated and clorgyline-treated pinealectomized hamsters. Repeated measures ANOVA indicated there were no significant differences between the effects of clorgyline on pinealectomized ( $\mathrm{Px}, n=3)$ and sham-operated $(S, n=2)$ hamsters for any of the dependent variables including $\mathrm{T}_{\mathrm{hy}}-24,(\mathrm{Px}=37.28 \pm$ $.07^{\circ} \mathrm{C}, 36.81 \pm .06,36.94 \pm .04$ [BL, Week 1, Week 3]; $\mathrm{S}=37.32 \pm .25,36.84 \pm .36,36.89 \pm .15 ; \mathrm{F}=0.4 ; d f=$ $2,6 ; \mathrm{NS}), \mathrm{T}_{\mathrm{hy}}-\mathrm{L}(\mathrm{Px}=37.01 \pm .01,36.51 \pm .05,36.66 \pm$ $.12 ; \mathrm{S}=37.09 \pm .15,36.54 \pm .29,36.67 \pm .03 ; \mathrm{F}=0.1$; $d f=2,6 ; \mathrm{NS}), \mathrm{T}_{\mathrm{hy}}-\mathrm{D}(\mathrm{Px}=37.65 \pm .05,37.24 \pm .15$, $37.33 \pm .13 ; \mathrm{S}=37.67 \pm .39,37.30 \pm .46,37.23 \pm .32$;

Table 2. Mean and Repeated Measures Anàlysis of Variance (ANOVA) Summary of Clorgyline $(n=6)$ Treatment Effects on Hypothalamic Temperature (Th) and Peritoneal (Tp) during Baseline, Week 1 and Week 2

\begin{tabular}{|c|c|c|c|c|c|c|c|c|c|}
\hline \multirow[b]{2}{*}{ Probe } & \multirow[b]{2}{*}{ Week } & \multicolumn{4}{|c|}{ 24-Hour } & \multicolumn{2}{|c|}{ Light Phase } & \multicolumn{2}{|c|}{ Dark Phase } \\
\hline & & $T-24$ & Range & Acrophase & Amplitude & T-L & T-L Min & T-D & T-D Max \\
\hline \multirow[t]{3}{*}{ Th } & Baseline & $\begin{array}{c}37.68^{a} \\
0.17\end{array}$ & $\begin{array}{l}2.05 \\
0.31\end{array}$ & $\begin{array}{c}17: 25^{b} \\
0: 02\end{array}$ & $\begin{array}{l}0.52 \\
0.09\end{array}$ & $\begin{array}{r}37.47 \\
0.19\end{array}$ & $\begin{array}{r}36.94 \\
0.19\end{array}$ & $\begin{array}{r}37.99 \\
0.20\end{array}$ & $\begin{array}{r}38.98 \\
0.28\end{array}$ \\
\hline & Week 1 & $\begin{array}{r}37.07 \\
0.10\end{array}$ & $\begin{array}{l}2.18 \\
0.38\end{array}$ & $\begin{array}{r}19: 14 \\
0: 38\end{array}$ & $\begin{array}{l}0.41 \\
0.08\end{array}$ & $\begin{array}{r}36.83 \\
0.15\end{array}$ & $\begin{array}{r}36.20 \\
0.27\end{array}$ & $\begin{array}{r}37.41 \\
0.09\end{array}$ & $\begin{array}{r}38.38 \\
0.22\end{array}$ \\
\hline & Week 2 & $\begin{array}{r}37.23 \\
0.12\end{array}$ & $\begin{array}{l}2.14 \\
0.33\end{array}$ & $\begin{array}{r}19: 06 \\
0: 55\end{array}$ & $\begin{array}{l}0.45 \\
0.10\end{array}$ & $\begin{array}{r}36.98 \\
0.14\end{array}$ & $\begin{array}{r}36.52 \\
0.20\end{array}$ & $\begin{array}{r}37.59 \\
0.20\end{array}$ & $\begin{array}{r}38.66 \\
0.30\end{array}$ \\
\hline \multirow[t]{3}{*}{$\mathrm{Tp}$} & Baseline & $\begin{array}{r}37.12 \\
0.42\end{array}$ & $\begin{array}{l}1.85 \\
0.34\end{array}$ & $\begin{array}{r}17: 56 \\
0: 19\end{array}$ & $\begin{array}{l}0.44 \\
0.10\end{array}$ & $\begin{array}{r}36.92 \\
0.42\end{array}$ & $\begin{array}{r}36.43 \\
0.34\end{array}$ & $\begin{array}{r}37.40 \\
0.43\end{array}$ & $\begin{array}{r}38.27 \\
0.48\end{array}$ \\
\hline & Week 1 & $\begin{array}{r}36.63 \\
0.38\end{array}$ & $\begin{array}{l}1.89 \\
0.62\end{array}$ & $\begin{array}{r}19: 21 \\
0: 43\end{array}$ & $\begin{array}{l}0.38 \\
0.08\end{array}$ & $\begin{array}{r}36.41 \\
0.41\end{array}$ & $\begin{array}{r}35.89 \\
0.48\end{array}$ & $\begin{array}{r}36.94 \\
0.36\end{array}$ & $\begin{array}{r}37.78 \\
0.55\end{array}$ \\
\hline & Week 2 & $\begin{array}{r}36.78 \\
0.42\end{array}$ & $\begin{array}{l}1.88 \\
0.32\end{array}$ & $\begin{array}{r}19: 32 \\
1: 00\end{array}$ & $\begin{array}{l}0.38 \\
0.12\end{array}$ & $\begin{array}{r}36.55 \\
0.41\end{array}$ & $\begin{array}{r}36.11 \\
0.48\end{array}$ & $\begin{array}{r}37.03 \\
0.46\end{array}$ & $\begin{array}{r}37.99 \\
0.47\end{array}$ \\
\hline \multicolumn{10}{|c|}{ ANOVA results } \\
\hline $\begin{array}{l}\mathrm{F} \\
d f \\
p<\end{array}$ & & $\begin{array}{c}127.16 \\
2,10 \\
0.0001\end{array}$ & $\begin{array}{c}0.193 \\
2,10 \\
\text { NS }\end{array}$ & $\begin{array}{c}14.27 \\
2,10 \\
0.002\end{array}$ & $\begin{array}{c}4.31 \\
2,10 \\
\text { NS }\end{array}$ & $\begin{array}{c}251.1 \\
2,10 \\
0.0001\end{array}$ & $\begin{array}{c}62.84 \\
2,10 \\
0.0001\end{array}$ & $\begin{array}{c}8.08 \\
2,10 \\
0.009\end{array}$ & $\begin{array}{c}33.75 \\
2,10 \\
0.0001\end{array}$ \\
\hline \multicolumn{10}{|l|}{ Probe } \\
\hline $\begin{array}{l}\text { F } \\
d f \\
p<\end{array}$ & & $\begin{array}{l}8.12 \\
1,15 \\
0.04\end{array}$ & $\begin{array}{c}1.328 \\
1,5 \\
\text { NS }\end{array}$ & $\begin{array}{c}37.845 \\
1,5 \\
0.002\end{array}$ & $\begin{array}{c}1.976 \\
1,5 \\
\text { NS }\end{array}$ & $\begin{array}{c}7.88 \\
1,5 \\
0.04\end{array}$ & $\begin{array}{l}4.2 \\
1,5 \\
\text { NS }\end{array}$ & $\begin{array}{c}9.301 \\
1,5 \\
0.03\end{array}$ & $\begin{array}{c}8.63 \\
1,5 \\
0.04\end{array}$ \\
\hline \multicolumn{10}{|c|}{ Week $\times$ probe } \\
\hline $\begin{array}{l}F \\
d f \\
p<\end{array}$ & & $\begin{array}{l}4.17 \\
2,10 \\
0.05\end{array}$ & $\begin{array}{c}0.667 \\
2,10 \\
\text { NS }\end{array}$ & $\begin{array}{c}2.392 \\
2,10 \\
\text { NS }\end{array}$ & $\begin{array}{l}1.566 \\
2,10 \\
\text { NS }\end{array}$ & $\begin{array}{l}4.11 \\
2,10 \\
\text { NS }\end{array}$ & $\begin{array}{l}2.69 \\
2,10 \\
\text { NS }\end{array}$ & $\begin{array}{l}2.07 \\
2,10 \\
\text { NS }\end{array}$ & $\begin{array}{l}1.404 \\
2,10 \\
\text { NS }\end{array}$ \\
\hline
\end{tabular}

${ }^{a}{ }^{\circ} \mathrm{C}$, Mean $\pm \mathrm{SD}$.

${ }^{b} \mathrm{HH}: \mathrm{MM}$, Mean $\pm \mathrm{SD}$. 

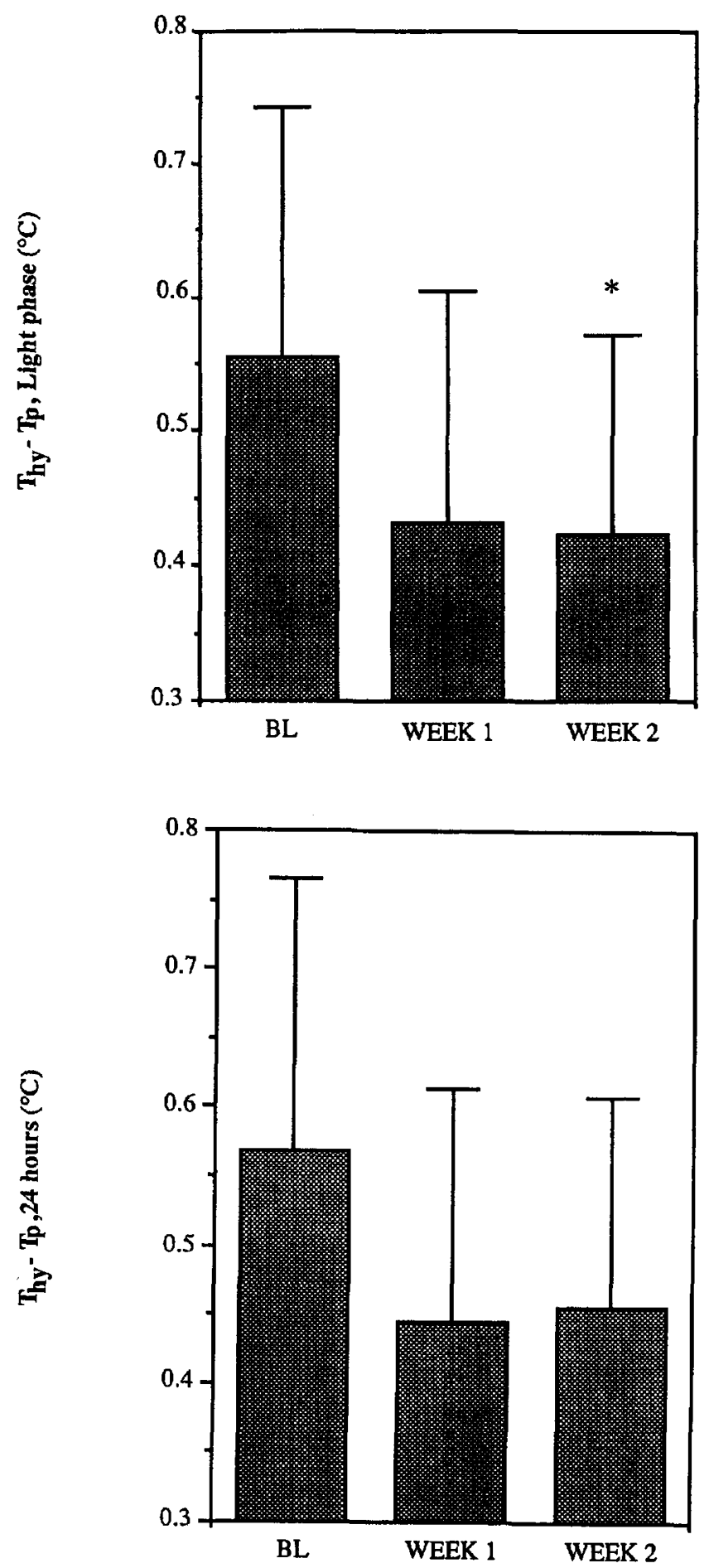

Figure 3. (Top) The difference between the mean ( \pm SEM) diurnal hypothalamic $\left(T_{h y}-L\right)$ and peritoneal $\left(T_{p}-L\right)$ temperatures during baseline ( $\mathrm{BL}, n=6)$, and during chronic clorgyline treatment (TR1 and TR2, $n=6$ ). $\mathrm{T}_{\text {hy }}$ was higher than $\mathrm{T}_{\mathrm{p}}$ at each phase of treatment, and clorgyline treatment (WEEK 1, WEEK 2) decreased the difference between $T_{\text {hy }}$ and $\mathrm{T}_{\mathrm{p}}(\mathrm{F}=4.11 ; d f=2,10 ; p<.05)$. The $\mathrm{T}_{\text {hy }} \mathrm{T}_{\mathrm{p}}$ difference $\left.{ }^{*}\right)$ during baseline $(\mathrm{BL})$ is significantly different from the difference measured during WEEK 2 (paired $t=2.74 ; d f=5 ; p=.041$ ), but not during WEEK 1 (paired $t=2.141 ; d f=5 ; p=.0852$ ). (Bottom) The difference between the mean ( \pm SEM) 24-hour
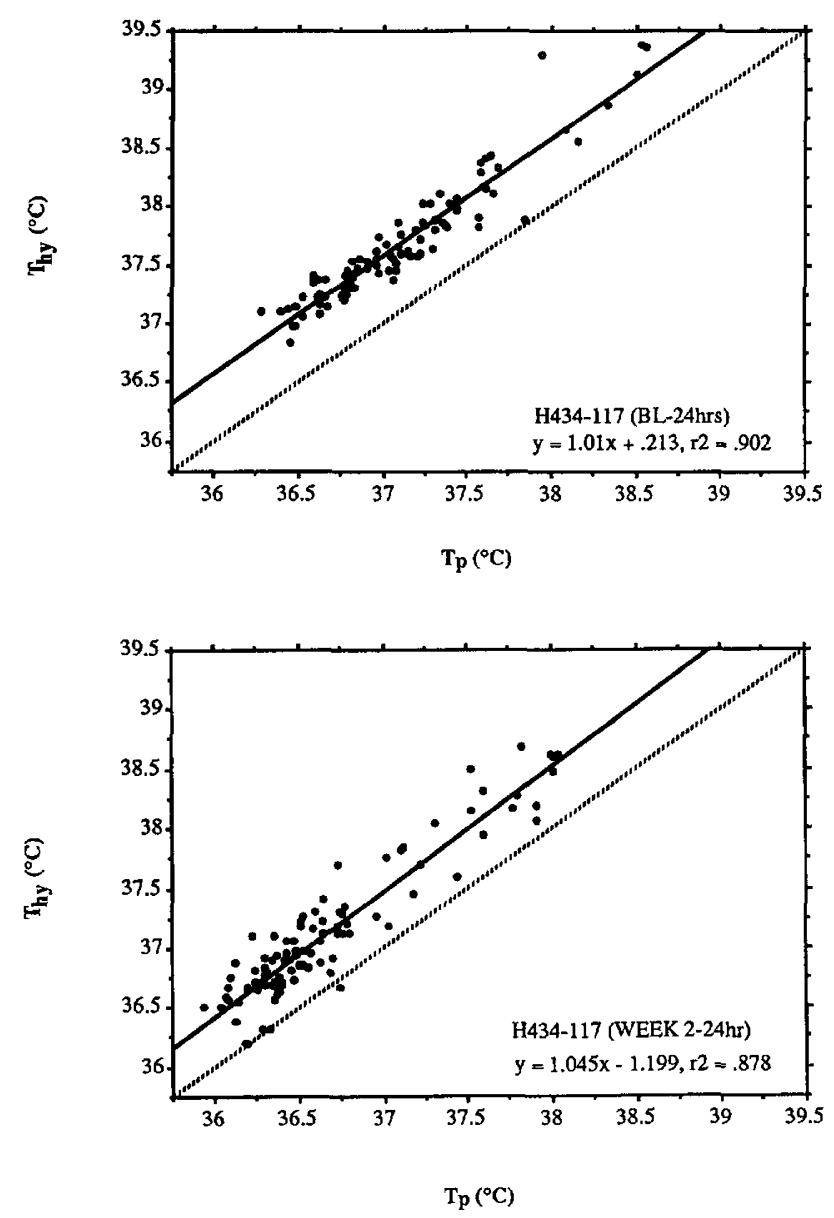

Figure 4. The linear regression (solid line) of $\mathrm{T}_{\text {hy }}$ on $\mathrm{T}_{\mathrm{p}}$ over the course of 24 hours during baseline (top) and during week 2 of clorgyline treatment (bottom) is shown for a representative animal. The relationship $\mathrm{T}_{\mathrm{hy}}=\mathrm{T}_{\mathrm{p}}$ is indicated by the broken line. $\mathrm{r} 2=\mathrm{r}^{2}=$ the proportion of the variance in $\mathrm{T}_{\mathrm{hy}}\left({ }^{\circ} \mathrm{C}\right)$ that is accounted for by its linear regression on $\mathrm{T}_{\mathrm{p}}\left({ }^{\circ} \mathrm{C}\right)$. The figure illustrates: $\mathrm{T}_{\text {hy }}>\mathrm{T}_{\mathrm{p}}$ during baseline and clorgyline treatment, clorgyline treatment decreases $T_{p}$ and $T_{h y}$, the uniform linear relationship between $T_{h y}$ and $T_{p}$ through $a$ range of body temperatures during baseline and clorgyline treatment, and the absence of selective hypothalamic cooling at elevated peritoneal temperatures.

hypothalamic $\left(\mathrm{T}_{\mathrm{hy}}-24\right)$ and peritoneal $\left(\mathrm{T}_{\mathrm{p}}-24\right)$ temperatures during baseline (BL), and during chronic clorgyline treatment (WEEK 1 and WEEK 2). As observed during T-L, chronic clorgyline treatment decreased the temperature difference between $\mathrm{T}_{\text {hy }}-24$ and $\mathrm{T}_{\mathrm{p}}-24(\mathrm{~F}=4.17 ; d f=2,10 ; p<0.05)$, but the pairwise comparisons between $B L$ and WEEK 1 , and $B L$ and WEEK 2, were not significant. 
$\mathrm{F}=1.0 ; d f=2,6 ; \mathrm{NS})$ and amplitude (Px $=0.55 \pm .11$, $0.49 \pm .12,0.46 \pm .15 ; \mathrm{S}=0.51 \pm .05,0.48 \pm .12 ; 0.35 \pm$ $.19, \mathrm{~F}=0.2 ; d f=2,6$; NS).

\section{Lithium}

Lithium's Effects on Hypothalamic Temperature in LD 14:10-Housed Hamsters. Increasing the dose of lithium periodically over an 8 week period produced a gradual drop in $\mathrm{T}_{\text {hy }}$. Low doses of lithium diet $(0.075 \%$ to $0.15 \%$ ), introduced during weeks 1 and 2 , had little effect on $\mathrm{T}_{\text {hy }}$ (Figure 5). Increasing lithium to $0.30 \%$ decreased the level of $T_{\text {hy }}$ after 1.5 weeks at this dose. Increasing lithium to $0.45 \%$ resulted in a further decline in the level of $T_{\text {hy. }}$. This decline was evident in both the peak and trough of $T_{\text {hy }}$ (Figure 7). A gradual decline in the level of $T_{\text {hy }}$ was observed in the control-diet hamsters, but this decline was smaller compared with the lithium-treated hamsters. In orbital blood samples taken from three of the four hamsters after 4 weeks of lithium treatment, plasma lithium levels were $0.61 \mathrm{mEq}$, $0.89 \mathrm{mEq}$ and $1.04 \mathrm{mEq}$. Plasma lithium levels measured in a separate group of hamsters ranged between 1.22 to $1.31 \mathrm{mEq} / \mathrm{L}$ at week 8 .
There were significant interactions between drug treatment (TRT: lithium versus control) and the week of treatment (BL, WEEK 4-5, WEEK 6-7) on $\mathrm{T}_{\text {hy-24 }}$ and $\mathrm{T}_{\text {hy }} \mathrm{L}$ (Table 3 ). Lithium significantly decreased $\mathrm{T}_{\text {hy }}-\mathrm{L}$ and $\mathrm{T}_{\text {hy-24 }}$ during WEEK 6-7 (Table 7).

\section{Fluoxetine}

The $2 \mathrm{mg} / \mathrm{kg} /$ day dose of fluoxetine produced a slight decrease in $T_{h y}$, most evident during the trough of the daily temperature curve (Figures 6 and 7). Increasing the dose of fluoxetine to $20 \mathrm{mg} / \mathrm{kg} /$ day (between weeks 2 and 4) produced a further decline. During fluoxetine withdrawal, $\mathrm{T}_{\mathrm{hy}}$ began to increase toward the levels observed during baseline.

Repeated measures ANOVA (BL, WEEK 1, WEEK 3, WEEK 4,WD) was used to determine the chronic effects of FLX on $\mathrm{T}_{\text {hy }}$ over 24 hours $\left(\mathrm{T}_{\text {hy-24) }}\right.$ ) and during the light $\left(T_{h y}-L\right)$ or dark phases $\left(T_{h y}-D\right)$. There were significant WEEK of treatment effects of amplitude ( $F=$ 6.288; $d f=4,16 ; p=0.017), \mathrm{T}_{\text {hy }} \mathrm{L}(\mathrm{F}=5.691 ; d f=4,16$; $p=.034), \mathrm{T}_{\text {hy }} \mathrm{L} \min (\mathrm{F}=5.463 ; d f=4,16 ; p=.04)$, and $\mathrm{T}_{\text {hy }} \mathrm{D} \max (\mathrm{F}=5.434 ; d f=4,16 ; p=.04)$. Fluoxetine decreased $\mathrm{T}_{\text {hy }}-\mathrm{L}$, delayed phase, and increased
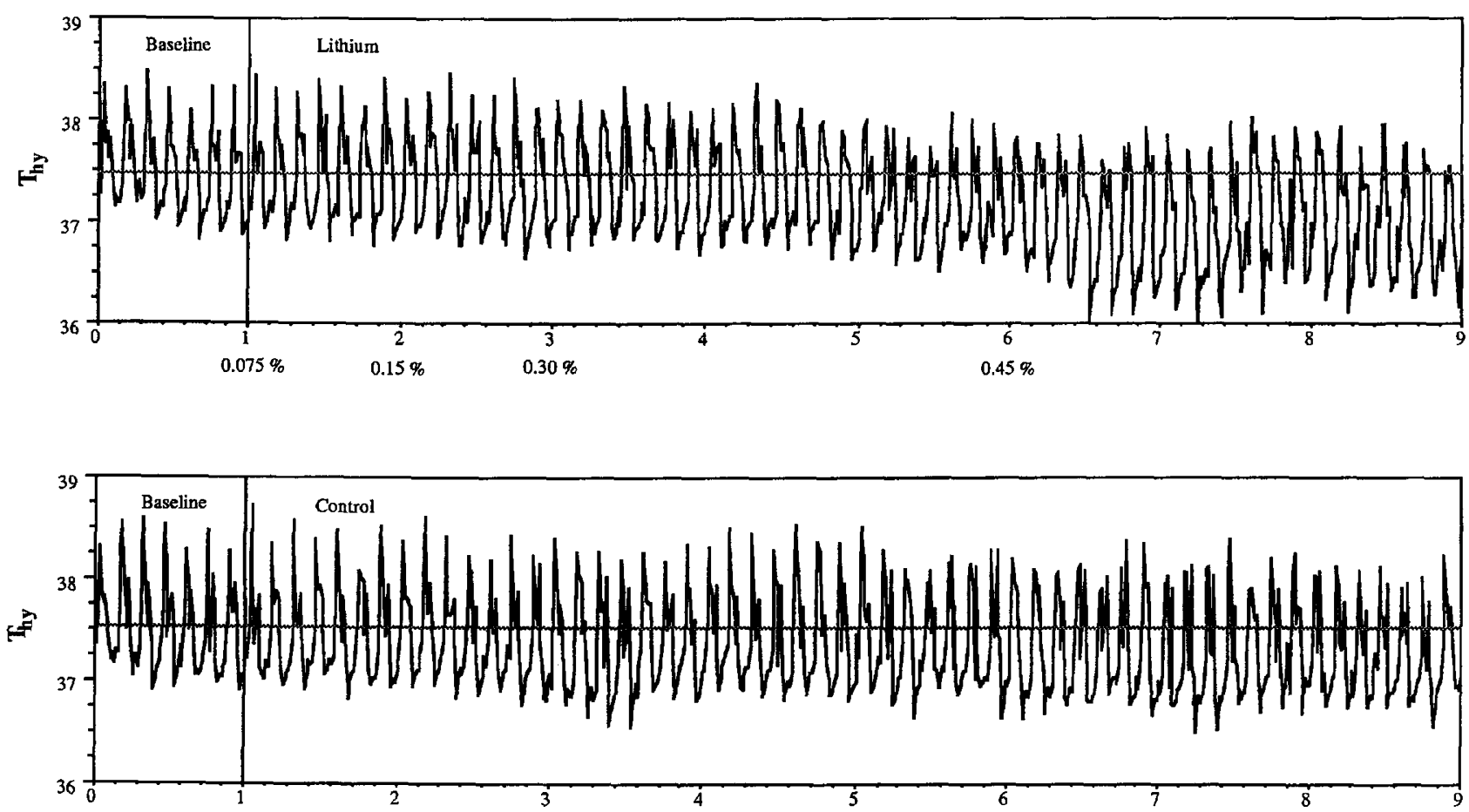

WEEK

Figure 5. The mean brain temperature $\left(\mathrm{T}_{\text {hy }}\right)$ of four lithium-treated hamsters (top) and three control (bottom) hamsters over the course of 9 weeks. Lithium diet $(0.075 \%)$ was administered to hamsters beginning week 1 ; dose was increased to $0.15 \%$, $0.30 \%$, and $0.45 \%$ on weeks 2,3 , and 6 respectively. Plasma lithium levels ranged from $0.61-1.04 \mathrm{mEq}$ after 4 weeks of treatment and about $1.22 \mathrm{mEq}$ at week 9 . The horizontal line corresponds to the mean baseline brain temperature for each group. 

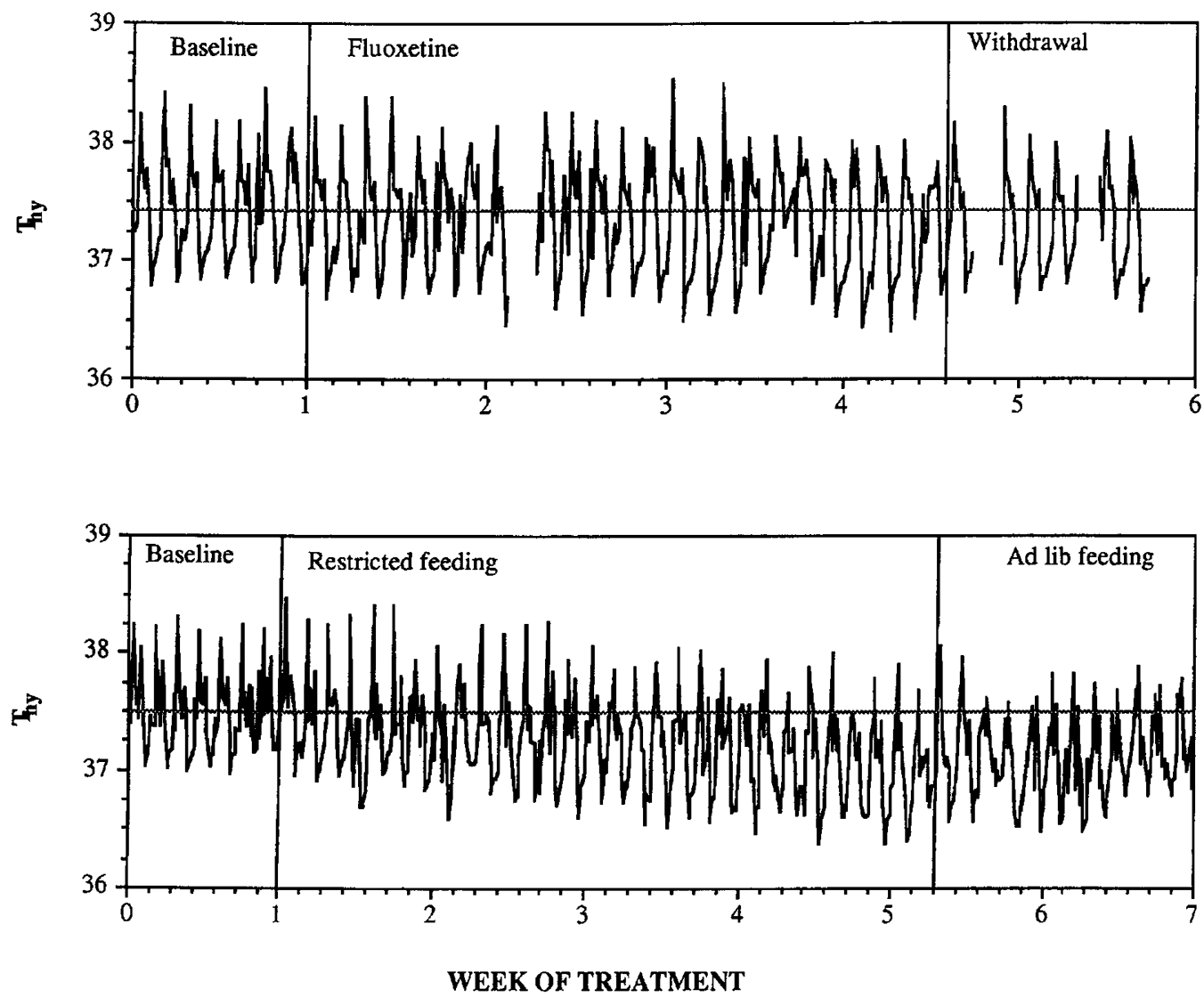

Figure 6. (Top panel) The mean brain temperature of five fluoxetine-treated hamsters treated for 25 days with fluoxetine by 8 days of withdrawal. Hamsters were treated with fluoxetine mixed in liquid diet $(\sim 2 \mathrm{mg} / \mathrm{kg} /$ day) beginning week 1 . After 1 week, the dose was increased to approximately $20 \mathrm{mg} / \mathrm{kg} /$ day. The transient increase in diurnal $\mathrm{T}_{\text {hy }}$ at day 25 was due to blood sampling. The gaps in the record were caused by technical malfunction. The horizontal line corresponds to the mean baseline temperature. (Lower panel) The mean temperature of three food-restricted hamsters. Daily food intake was limited to $80 \%$ to $90 \%$ of the ad lib baseline levels for 30 days. On day 31 , hamsters were again allowed to feed ad lib.

amplitude during WEEK 3 and WEEK 4. Fluoxetine also increased $T_{\text {hy }}$ ranged, $T_{\text {hy }}-\mathrm{D}$ max, and range during WEEK 3 (Table 7).

Daily food intake decreased in hamsters fed fluoxetine in a liquid diet. To assess whether fluoxetine's effects on temperature were related to decreased food consumption, $T_{\text {hy }}$ was monitored in untreated animals whose food was restricted to the average weekly amount that was consumed by FLX-treated hamsters (Figure 6). There were no significant differences between the FLX-treated and food-restricted hamsters for $\mathrm{T}_{\text {hy }}$-24, 24-hour range, $\mathrm{T}_{\text {hy }}-\mathrm{L}$, $\mathrm{T}_{\text {hy }}-\mathrm{L}$ min, $\mathrm{T}_{\text {hy }}-\mathrm{D}$, or
$\mathrm{T}_{\text {hy-D }} \mathrm{D}$ max. There were significant interactions between the two groups and the week of treatment of 24hour range, $\mathrm{T}_{\text {hy }}-\mathrm{D}, \mathrm{T}_{\text {hy }} \mathrm{D}$ max, and acrophase (Table 4). The acrophase of $T_{\text {hy }}$ was significantly delayed in FLX-treated hamsters compared with restricted-diet hamsters during WEEK $3(t=3.644 ; d f=6 ; p<.02)$, WEEK $4(t=7.891 ; d f=6 ; p<.002)$ and during withdrawal (WD; $t=2.476 ; d f=6 ; p<.05$ ).

During week $3,1.5 \mathrm{ml}$ of blood was extracted from the orbital sinus of each hamster. This procedure was associated with a transient 2 day to 3 day rise in the level of $\mathrm{T}_{\text {hy }}$ (Figure 6 ). Averaged fluoxetine and norfluoxetine

Figure 7. The average 24-hour patterns of brain temperature in chronic clorgyline (top), lithium (middle), and fluoxetine (bottom) treated hamsters during baseline (shaded area = mean $\pm 1 \mathrm{SEM}$ ), and during chronic treatment (heavy black line). The dotted (baseline) and thin lines (chronic drug treatment) correspond to the best-fit line to the data using a 24-hour cosine plus three harmonics. Compared with baseline, the average hypothalamic temperature during the light phase (0100 hours to 1500 hours) was significantly decreased in clorgyline (paired $t=19.22, d f=4, p=.0001$ ), fluoxetine (paired $t=3.094$, $d f=4, p=.036)$, and in lithium-treated hamsters $(t=6.263, d f=3, p=.008)$. Lithium and clorgyline also significantly decreased the average 24-hour temperature. 

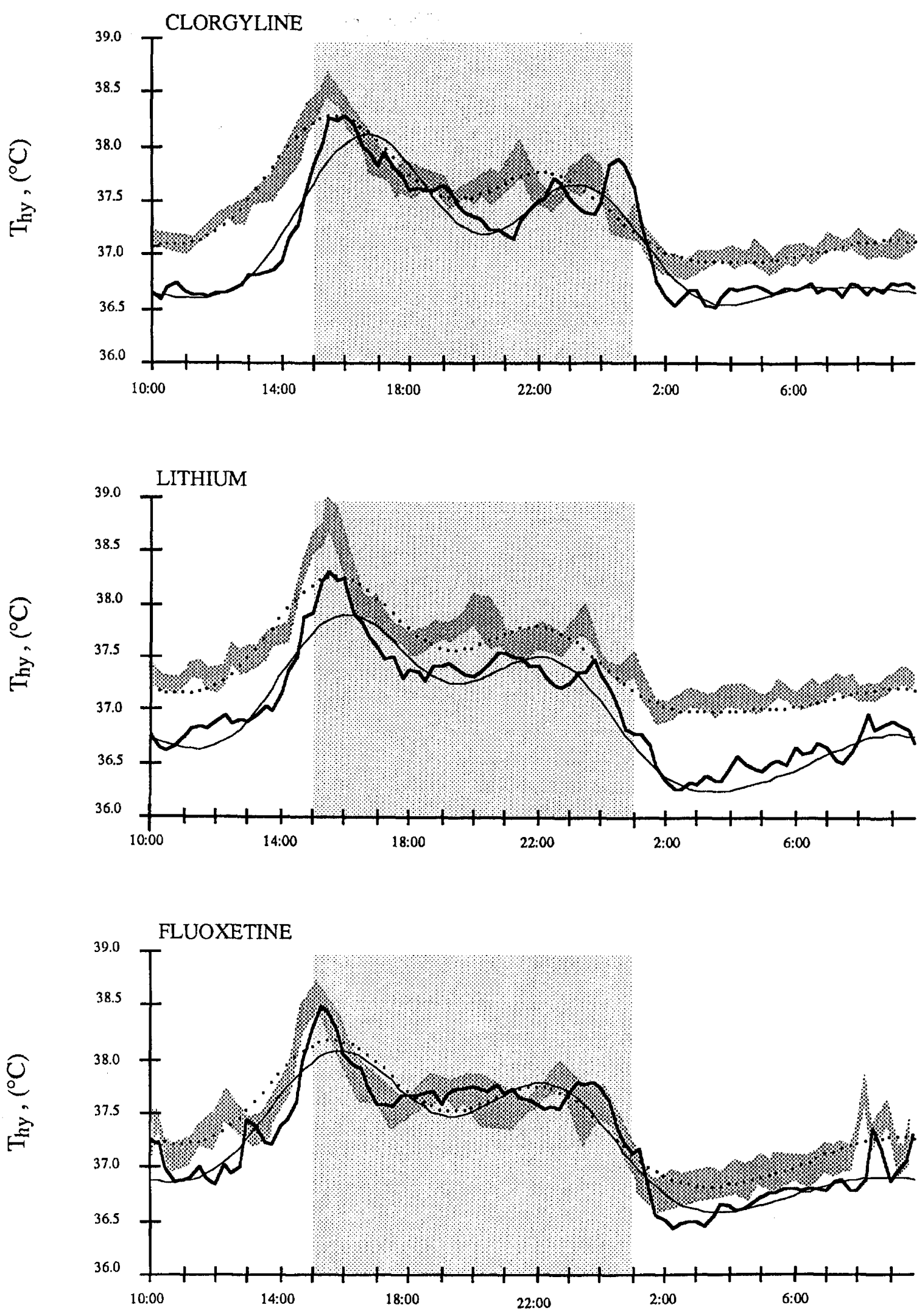

CLOCKTIME 
Table 3. Mean and Repeated Measures Analysis of Variance (ANOVA) Summary of Lithium $(n=4)$ and Control $(n=3)$ Treatment Effects on Hypothalamic Temperature (Th) during Baseline, Week 4-5, and Week 6-7

\begin{tabular}{|c|c|c|c|c|c|c|c|c|c|}
\hline \multirow[b]{2}{*}{ Treatment } & \multirow[b]{2}{*}{ Week } & \multicolumn{4}{|c|}{ 24-Hour } & \multicolumn{2}{|c|}{ Light Phase } & \multicolumn{2}{|c|}{ Dark Phase } \\
\hline & & Th-24 & Range & Acrophase & Amplitude & Th-L & Th-L Min & Th-D & Th-D Max \\
\hline \multirow[t]{3}{*}{ Lithium } & Baseline & $\begin{array}{c}37.46^{a} \\
0.15\end{array}$ & $\begin{array}{l}2.00 \\
0.38\end{array}$ & $\begin{array}{c}17: 26^{b} \\
0: 23\end{array}$ & $\begin{array}{l}0.49 \\
0.06\end{array}$ & $\begin{array}{r}37.22 \\
0.17\end{array}$ & $\begin{array}{r}36.82 \\
0.26\end{array}$ & $\begin{array}{r}37.81 \\
0.16\end{array}$ & $\begin{array}{r}38.82 \\
0.37\end{array}$ \\
\hline & Week 4-5 & $\begin{array}{c}37.27 \\
0.3\end{array}$ & $\begin{array}{l}2.16 \\
0.09\end{array}$ & $\begin{array}{r}17: 39 \\
0: 47\end{array}$ & $\begin{array}{l}0.57 \\
0.10\end{array}$ & $\begin{array}{c}36.97 \\
0.2\end{array}$ & $\begin{array}{r}36.52 \\
0.35\end{array}$ & $\begin{array}{r}37.69 \\
0.44\end{array}$ & $\begin{array}{r}38.68 \\
0.29\end{array}$ \\
\hline & Week 6-7 & $\begin{array}{l}37 \\
0.17\end{array}$ & $\begin{array}{l}2.24 \\
0.22\end{array}$ & $\begin{array}{r}17: 30 \\
1: 07\end{array}$ & $\begin{array}{l}0.65 \\
0.16\end{array}$ & $\begin{array}{r}36.65 \\
0.06\end{array}$ & $\begin{array}{r}36.09 \\
0.23\end{array}$ & $\begin{array}{r}37.48 \\
0.34\end{array}$ & $\begin{array}{r}38.32 \\
0.23\end{array}$ \\
\hline \multirow[t]{3}{*}{ Control } & Baseline & $\begin{array}{c}37.5 \\
0.08\end{array}$ & $\begin{array}{l}2.05 \\
0.04\end{array}$ & $\begin{array}{r}17: 24 \\
0: 27\end{array}$ & $\begin{array}{l}0.52 \\
0.06\end{array}$ & $\begin{array}{r}37.25 \\
0.08\end{array}$ & $\begin{array}{r}36.82 \\
0.01\end{array}$ & $\begin{array}{r}37.86 \\
0.06\end{array}$ & $\begin{array}{r}38.87 \\
0.03\end{array}$ \\
\hline & Week 4-5 & $\begin{array}{r}37.46 \\
0.12\end{array}$ & $\begin{array}{l}2.01 \\
0.19\end{array}$ & $\begin{array}{r}17: 18 \\
0: 14\end{array}$ & $\begin{array}{l}0.50 \\
0.12\end{array}$ & $\begin{array}{c}37.2 \\
0.09\end{array}$ & $\begin{array}{r}36.82 \\
0.09\end{array}$ & $\begin{array}{r}37.76 \\
0.18\end{array}$ & $\begin{array}{r}38.83 \\
0.26\end{array}$ \\
\hline & Week 6-7 & $\begin{array}{r}37.36 \\
0.14\end{array}$ & $\begin{array}{l}2.02 \\
0.18\end{array}$ & $\begin{array}{r}17: 37 \\
0: 06\end{array}$ & $\begin{array}{l}0.53 \\
0.12\end{array}$ & $\begin{array}{r}37.08 \\
0.15\end{array}$ & $\begin{array}{r}36.65 \\
0.21\end{array}$ & $\begin{array}{r}37.74 \\
0.15\end{array}$ & $\begin{array}{r}38.67 \\
0.07\end{array}$ \\
\hline \multicolumn{10}{|c|}{ ANOVA results } \\
\hline $\begin{array}{l}\mathbf{F} \\
d f \\
p<\end{array}$ & & $\begin{array}{c}6.481 \\
2,10 \\
0.016\end{array}$ & $\begin{array}{l}0.62 \\
2,10 \\
\text { NS }\end{array}$ & $\begin{array}{l}0.22 \\
2,10 \\
\text { NS }\end{array}$ & $\begin{array}{l}2.07 \\
2,10 \\
\text { NS }\end{array}$ & $\begin{array}{c}7.52 \\
2,10 \\
0.01\end{array}$ & $\begin{array}{c}4.755 \\
2,10 \\
0.035\end{array}$ & $\begin{array}{l}1.46 \\
2,10 \\
\text { NS }\end{array}$ & $\begin{array}{c}0.79 \\
2,10 \\
\text { NS }\end{array}$ \\
\hline
\end{tabular}

$a{ }^{\circ} \mathrm{C}$, Mean $\pm \mathrm{SD}$.

${ }^{b} \mathrm{HH}: \mathrm{MM}$, Mean $\pm \mathrm{SD}$.

plasma levels at this time were $41 \pm 5.5 \mathrm{ng} / \mathrm{mL}$ and 326 $\pm 63.5 \mathrm{ng} / \mathrm{ml}$, respectively.

\section{CHRONIC NEUROLEPTIC DRUG TREATMENT EFFECTS ON BODY TEMPERATURE}

\section{Chlorpromazine and Haloperidol}

$\mathrm{T}_{\text {hy }}$ decreased $1^{\circ} \mathrm{C}$ during the first day of chlorpromazine treatment (Figure 8). Afterwards, the trough of $T_{\text {hy }}$ rose transiently for about 2 days and then declined toward baseline values. For the next 10 days of treatment, the pattern of $\mathrm{T}_{\text {hy }}$ appeared to be qualitatively similar to baseline (Figures 8 and 9). Two factor ANOVA with repeated measures indicated that there were no significant interactions on $T_{\text {hy }}$ between treatment and week of treatment for the dependent variables $T_{\text {hy }}-24$, 24-hour range, $T_{\text {hy }}-\mathrm{L}, \mathrm{T}_{\text {hy }}-\mathrm{L}$ min, $\mathrm{T}_{\text {hy }}-\mathrm{D}$, and $\mathrm{T}_{\text {hy }}-\mathrm{D}$ max. There was a significant interaction between treatment and week of treatment on cosinor estimated amplitude $(\mathrm{F}=7.762 ; d f=4,16 ; p=.001)$, but no differences between cell means of chlorpromazine, haloperidol, or controls during WEEK 1 , or WEEK 2 (Table 5).

In experiments conducted without monitoring $T_{\text {hy }}$, chlorpromazine plasma levels ranged between $85 \mathrm{ng} / \mathrm{ml}$ and $115 \mathrm{ng} / \mathrm{ml}$ on the third day of treatment. The plasma level was $11 \mathrm{ng} / \mathrm{ml}$ in one hamster and was undetectable in three of the four hamsters after 2 weeks of treatment. Hamsters treated with $25 \mathrm{mg}$ haldol pellets, but without $\mathrm{T}_{\text {hy }}$ monitoring, had plasma haloperidol levels of $12.75 \mathrm{ng} / \mathrm{ml}$ and $3.75 \mathrm{ng} / \mathrm{ml}$ after 3 days $(n=4)$ and 2 weeks $(n=4)$ of treatment, respectively.

\section{Haloperidol Decanoate 100}

Injection with haloperidol decanoate 100 produced a 1.5 week elevation of $T_{\text {hy }}$ (Figure 8). Plasma drug levels measured in separate groups of hamsters after $4(n=$ $4), 16(n=4)$ and $21(n=5)$ days of treatment averaged $20.25 \mathrm{ng} / \mathrm{ml}, 15.5 \mathrm{ng} / \mathrm{ml}$ and $6.0 \mathrm{ng} / \mathrm{ml}$ respectively. Injection of sesame oil vehicle was not associated with an increase in $T_{\text {hy. }}$. Two factor ANOVA with repeated measures indicated a significant interaction between TRT (haloperidol, vehicle) and measures (BL, WEEK 2, WEEK 3) for $\mathrm{T}_{\text {hy }}-\mathrm{L}$ minutes $(\mathrm{F}=8.77 ; d f=2,6 ; p=$ $.02)$, and a trend for $T_{\text {hy }}-\mathrm{L}(\mathrm{F}=5.96 ; d f=2,6 ; p=.07)$. There was a significant interaction between treatment and week of treatment for cosine estimated amplitude $(\mathrm{F}=13.40 ; d f=2,6 ; p<.05)$. Haloperidol decanoate 100 significantly decreased the amplitude in treated animals compared with controls during WEEK $2(t=$ 3.853; $d f=3 ; p<.04)$, and this effect lessened during WEEK 3 ( $t=2.797 ; d f=3 ; p<.07)$.

\section{DRUG EFFECTS ON BODY MASS}

Hamsters treated with the neuroleptics, lithium, and clorgyline lost body mass, whereas those treated with 
Table 4. Mean and Repeated Measures Analysis of Variance (ANOVA) Summary of Fluoxetine $(n=5)$ and Control $(n=3)$ Treatment Effects on Hypothalamic Temperature (Th) during Baseline, Week 1, Week 3, Week 4, and Withdrawal

\begin{tabular}{|c|c|c|c|c|c|c|c|c|c|}
\hline \multirow[b]{2}{*}{ Treatment } & \multirow[b]{2}{*}{ Week } & \multicolumn{4}{|c|}{ 24-Hour } & \multicolumn{2}{|c|}{ Light Phase } & \multicolumn{2}{|c|}{ Dark Phase } \\
\hline & & Th-24 & Range & Acrophase & Amplitude & Th-L & Th-L Min & Th-D & Th-D Max \\
\hline \multirow[t]{5}{*}{ Fluoxetine } & Baseline & $\begin{array}{c}37.43^{a} \\
0.26\end{array}$ & $\begin{array}{l}2.01 \\
0.13\end{array}$ & $\begin{array}{c}17: 00^{b} \\
0: 22\end{array}$ & $\begin{array}{l}0.48 \\
0.07\end{array}$ & $\begin{array}{r}37.19 \\
0.27\end{array}$ & $\begin{array}{c}36.7 \\
0.32\end{array}$ & $\begin{array}{r}37.77 \\
0.28\end{array}$ & $\begin{array}{r}38.70 \\
0.22\end{array}$ \\
\hline & Week 1 & $\begin{array}{r}37.35 \\
0.31\end{array}$ & $\begin{array}{l}1.73 \\
0.25\end{array}$ & $\begin{array}{r}16: 35 \\
0: 46\end{array}$ & $\begin{array}{l}0.47 \\
0.12\end{array}$ & $\begin{array}{c}37.15 \\
0.3\end{array}$ & $\begin{array}{r}36.67 \\
0.37\end{array}$ & $\begin{array}{r}37.64 \\
0.36\end{array}$ & $\begin{array}{r}38.40 \\
0.37\end{array}$ \\
\hline & Week 3 & $\begin{array}{r}37.33 \\
0.32\end{array}$ & $\begin{array}{l}2.25 \\
0.30\end{array}$ & $\begin{array}{r}17: 43 \\
0: 38\end{array}$ & $\begin{array}{l}0.62 \\
0.08\end{array}$ & $\begin{array}{r}37.00 \\
0.33\end{array}$ & $\begin{array}{c}36.5 \\
0.41\end{array}$ & $\begin{array}{r}37.78 \\
0.32\end{array}$ & $\begin{array}{r}38.75 \\
0.27\end{array}$ \\
\hline & Week 4 & $\begin{array}{r}37.26 \\
0.34\end{array}$ & $\begin{array}{l}2.23 \\
0.26\end{array}$ & $\begin{array}{r}17: 56 \\
0: 18\end{array}$ & $\begin{array}{l}0.60 \\
0.13\end{array}$ & $\begin{array}{r}36.92 \\
0.38\end{array}$ & $\begin{array}{r}36.37 \\
0.45\end{array}$ & $\begin{array}{r}37.75 \\
0.31\end{array}$ & $\begin{array}{r}38.60 \\
0.23\end{array}$ \\
\hline & Withdrawal & $\begin{array}{r}37.29 \\
0.36\end{array}$ & $\begin{array}{l}1.94 \\
0.81\end{array}$ & $\begin{array}{r}17: 09 \\
0: 21\end{array}$ & $\begin{array}{l}0.55 \\
0.08\end{array}$ & $\begin{array}{r}37.02 \\
0.37\end{array}$ & $\begin{array}{r}36.52 \\
0.36\end{array}$ & $\begin{array}{r}37.64 \\
0.37\end{array}$ & $\begin{array}{r}38.45 \\
0.31\end{array}$ \\
\hline \multirow[t]{5}{*}{ Food restriction } & Baseline & $\begin{array}{r}37.48 \\
0.44\end{array}$ & $\begin{array}{l}1.54 \\
0.40\end{array}$ & $\begin{array}{r}17: 07 \\
0: 01\end{array}$ & $\begin{array}{l}0.32 \\
0.12\end{array}$ & $\begin{array}{r}37.31 \\
0.50\end{array}$ & $\begin{array}{r}36.84 \\
0.58\end{array}$ & $\begin{array}{r}37.70 \\
0.36\end{array}$ & $\begin{array}{r}38.38 \\
0.21\end{array}$ \\
\hline & Week 1 & $\begin{array}{r}37.42 \\
0.45\end{array}$ & $\begin{array}{l}1.70 \\
0.49\end{array}$ & $\begin{array}{r}16: 46 \\
0: 22\end{array}$ & $\begin{array}{l}0.38 \\
0.15\end{array}$ & $\begin{array}{r}37.26 \\
0.51\end{array}$ & $\begin{array}{r}36.78 \\
0.73\end{array}$ & $\begin{array}{r}37.64 \\
0.37\end{array}$ & $\begin{array}{r}38.48 \\
0.28\end{array}$ \\
\hline & Week 3 & $\begin{array}{c}37.3 \\
0.45\end{array}$ & $\begin{array}{l}1.59 \\
0.54\end{array}$ & $\begin{array}{r}16: 09 \\
0: 27\end{array}$ & $\begin{array}{l}0.45 \\
0.17\end{array}$ & $\begin{array}{r}37.15 \\
0.52\end{array}$ & $\begin{array}{r}36.62 \\
0.65\end{array}$ & $\begin{array}{r}37.50 \\
0.34\end{array}$ & $\begin{array}{r}38.21 \\
0.21\end{array}$ \\
\hline & Week 4 & $\begin{array}{r}37.06 \\
0.41\end{array}$ & $\begin{array}{l}1.97 \\
0.54\end{array}$ & $\begin{array}{r}16: 08 \\
0: 18\end{array}$ & $\begin{array}{l}0.47 \\
0.19\end{array}$ & $\begin{array}{r}36.92 \\
0.45\end{array}$ & $\begin{array}{r}36.31 \\
0.55\end{array}$ & $\begin{array}{r}37.27 \\
0.37\end{array}$ & $\begin{array}{r}38.28 \\
0.45\end{array}$ \\
\hline & Withdrawal & $\begin{array}{c}37.2 \\
0.33\end{array}$ & $\begin{array}{l}1.59 \\
0.50\end{array}$ & $\begin{array}{r}15: 51 \\
1: 08\end{array}$ & $\begin{array}{l}0.39 \\
0.11\end{array}$ & $\begin{array}{r}37.08 \\
0.40\end{array}$ & $\begin{array}{r}36.63 \\
0.53\end{array}$ & $\begin{array}{r}37.36 \\
0.25\end{array}$ & $\begin{array}{r}38.23 \\
0.29\end{array}$ \\
\hline \multicolumn{10}{|c|}{ ANOVA results } \\
\hline $\begin{array}{l}F \\
d f \\
p<\end{array}$ & & $\begin{array}{c}2.285 \\
4,24 \\
0.09\end{array}$ & $\begin{array}{l}3.70 \\
4,24 \\
0.018\end{array}$ & $\begin{array}{l}4.64 \\
4,24 \\
0.05\end{array}$ & $\begin{array}{l}0.70 \\
4,24 \\
\text { NS }\end{array}$ & $\begin{array}{l}0.70 \\
4,24 \\
\text { NS }\end{array}$ & $\begin{array}{l}0.6 \\
4,24 \\
\text { NS }\end{array}$ & $\begin{array}{c}4.67 \\
4,24 \\
0.006\end{array}$ & $\begin{array}{l}3.50 \\
4,24 \\
0.022\end{array}$ \\
\hline
\end{tabular}

${ }^{a}{ }^{\circ} \mathrm{C}$, Mean $\pm \mathrm{SD}$.

${ }^{b} \mathrm{HH}: \mathrm{MM}$, Mean $\pm \mathrm{SD}$.
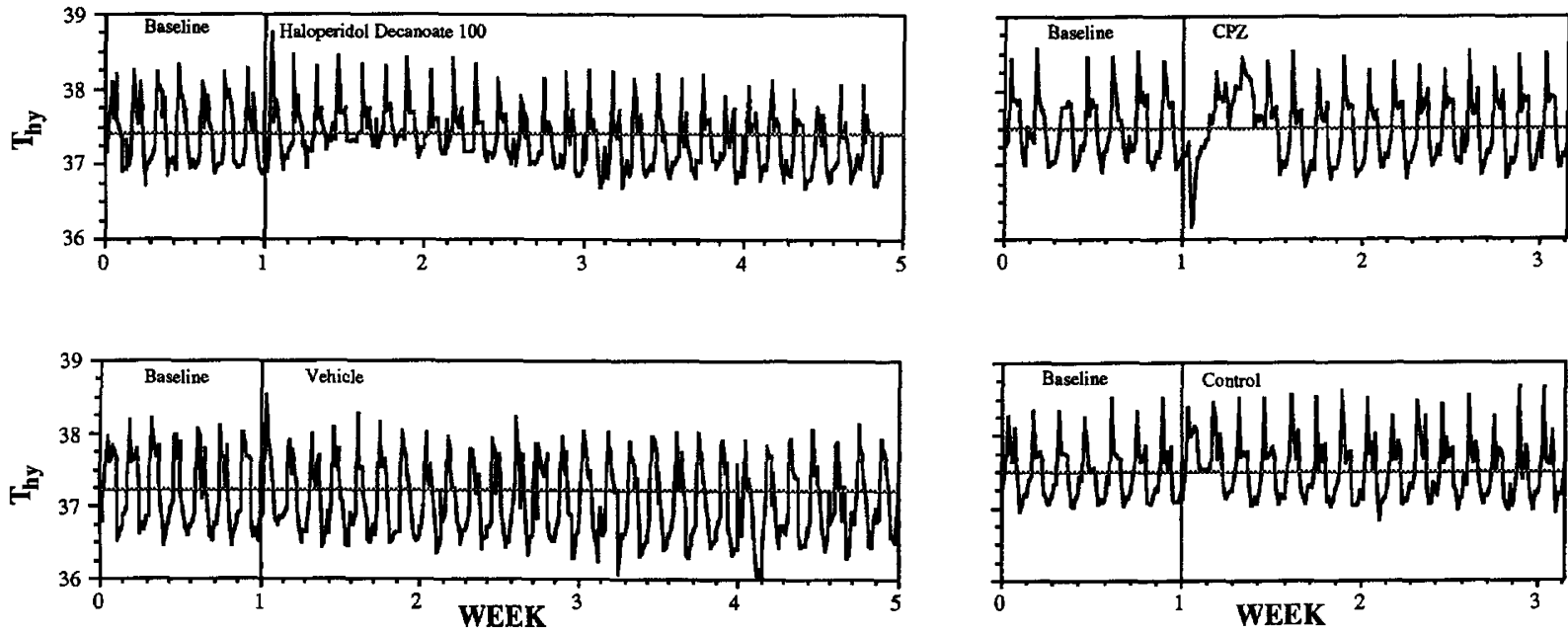

Figure 8. Left panels: The mean brain temperature of three hamsters treated with haldol decanoate 100 (top) and two hamsters treated with sesame oil vehicle. Right panels: The mean brain temperature of five chlorpromazine (top) and three control hamsters (bottom) over the course of $\mathbf{2 3}$ days are shown. Hamsters were treated with 3-week, timed-release chlorpromazine $(100 \mathrm{mg})$, or control pellets. The horizontal line corresponds to the mean baseline temperature for each group. 


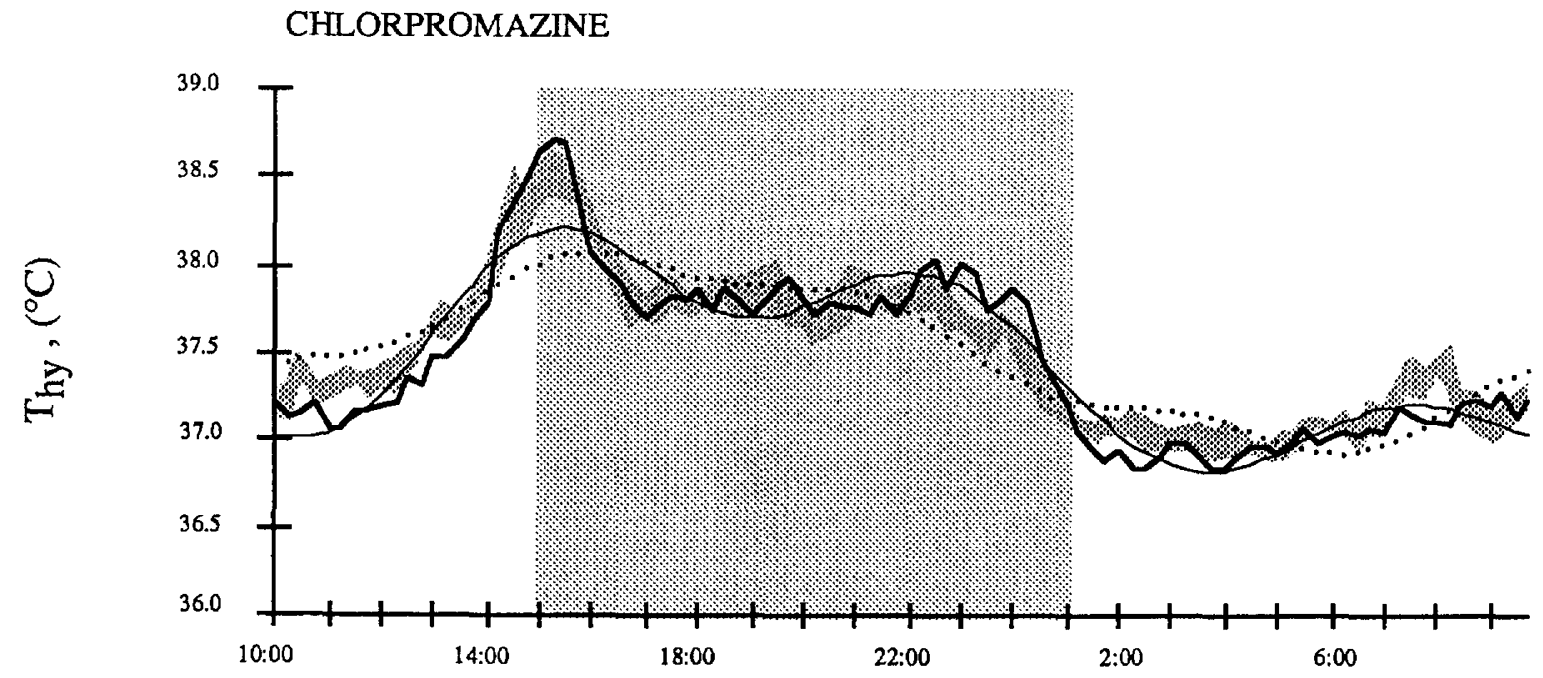

HALOPERIDOL DECANOATE

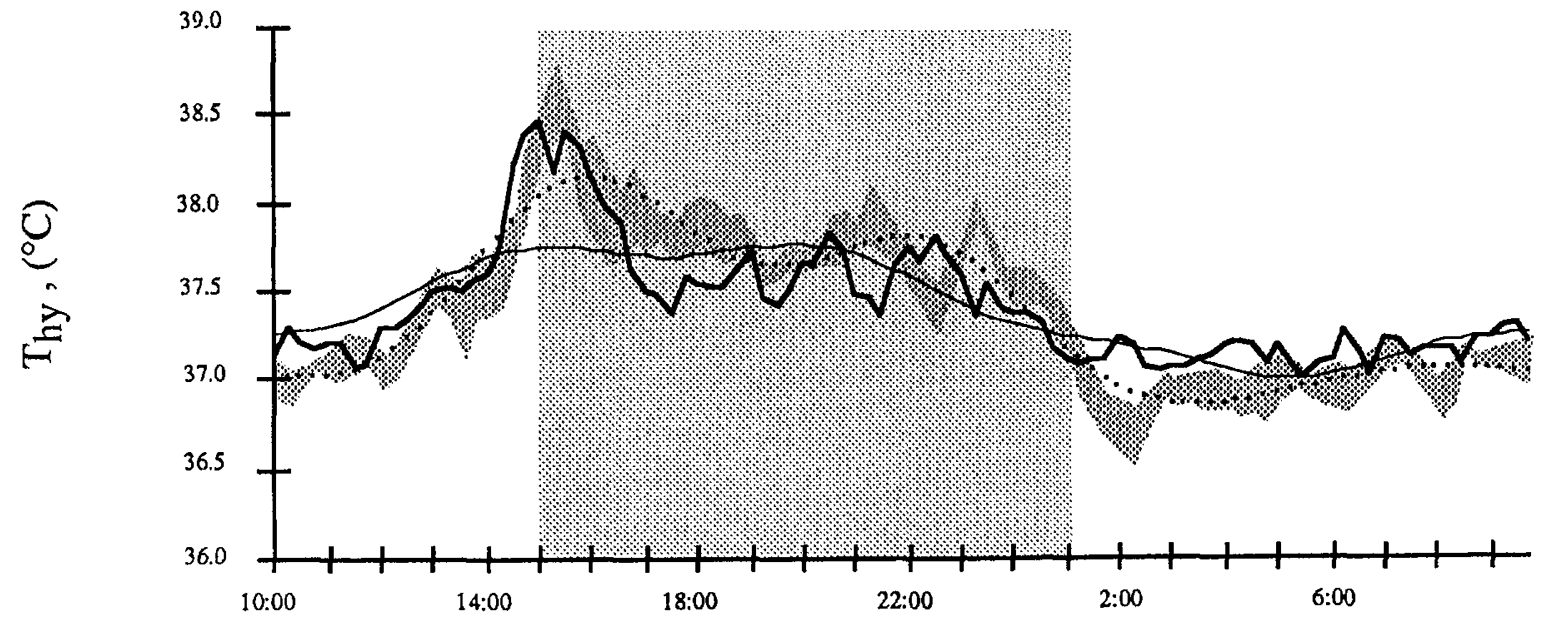

\section{CLOCKTIME}

Figure 9. The 24-hour pattern of brain temperature in chronic chlorpromazine $($ top, $\mathrm{n}=5)$ and haldol $($ bottom, $\mathrm{n}=3)$ treated hamsters during baseline (shown in grey $\pm 1 \mathrm{SEM}$ ), and during chronic treatment days 7 to 13 (heavy black line). The dotted (baseline) and thin lines (chronic drug treatment) correspond to the best-fit line to the data using a 24-hour cosine plus three harmonics. The differences between treatment and controls were not significant.

fluoxetine, and control hamsters showed negligible effects, or gained body mass (Figure 10).

\section{DISCUSSION}

The major finding of these experiments was that the antidepressant drugs clorgyline, fluoxetine, and lithium decreased hypothalamic temperature (Tables 1, 3, 4, and 7). The decrease was most pronounced during the light-(rest-) phase of the 24-hour cycle. Less general effects of the antidepressant drugs on the daily pattern of $T_{\text {hy }}$ were also observed. Both clorgyline (Tables 1 and 7) and fluoxetine (Tables 4 and 7) delayed the circadian rhythm of $T_{h y}$, and fluoxetine increased the circadian amplitude of $\mathrm{T}_{\text {hy }}$. Clorgyline also decreased $\mathrm{T}_{\text {hy }}$ over 24 hours and during the circadian activity phase, but these effects were only present during the first week of treatment. In contrast, neither subchronic or chronic treatment with the neuroleptic drugs, chlorpromazine, 
Table 5. Mean and Repeated Measures Analysis of Variance (ANOVA) Summary of Chlorpromazine $(\mathrm{Cpz}, n=5)$, Haldol $(n=3)$, and Placebo $(n=3)$ Treatment Effects on Hypothalamic Temperature (Th) during Baseline, Week 1 and Week 2

\begin{tabular}{|c|c|c|c|c|c|c|c|c|c|}
\hline \multirow[b]{2}{*}{ Treatment } & \multirow[b]{2}{*}{ Week } & \multicolumn{4}{|c|}{ 24-Hour } & \multicolumn{2}{|c|}{ Light Phase } & \multicolumn{2}{|c|}{ Dark Phase } \\
\hline & & Th-24 & Range & Acrophase & Amplitude & Th-L & Th-L Min & Th-D & Th-D Max \\
\hline \multirow[t]{3}{*}{ Cpz } & Baseline & $\begin{array}{c}37.52^{a} \\
0.05\end{array}$ & $\begin{array}{l}1.814 \\
0.29\end{array}$ & $\begin{array}{c}17: 18^{b} \\
0: 21\end{array}$ & $\begin{array}{l}0.51 \\
0.07\end{array}$ & $\begin{array}{r}37.28 \\
0.06\end{array}$ & $\begin{array}{c}36.852 \\
0.14\end{array}$ & $\begin{array}{c}37.842 \\
0.06\end{array}$ & $\begin{array}{c}38.652 \\
0.25\end{array}$ \\
\hline & Week 1 & $\begin{array}{r}37.55 \\
0.09\end{array}$ & $\begin{array}{l}1.68 \\
0.19\end{array}$ & $\begin{array}{r}17: 02 \\
0: 37\end{array}$ & $\begin{array}{l}0.45 \\
0.07\end{array}$ & $\begin{array}{r}37.36 \\
0.09\end{array}$ & $\begin{array}{r}36.88 \\
0.18\end{array}$ & $\begin{array}{r}37.83 \\
0.15\end{array}$ & $\begin{array}{r}38.56 \\
0.22\end{array}$ \\
\hline & Week 2 & $\begin{array}{r}37.50 \\
0.08\end{array}$ & $\begin{array}{l}2.16 \\
0.22\end{array}$ & $\begin{array}{r}17: 47 \\
0: 31\end{array}$ & $\begin{array}{l}0.56 \\
0.08\end{array}$ & $\begin{array}{r}37.25 \\
0.09\end{array}$ & $\begin{array}{r}36.77 \\
0.12\end{array}$ & $\begin{array}{r}37.86 \\
0.15\end{array}$ & $\begin{array}{r}38.75 \\
0.18\end{array}$ \\
\hline \multirow[t]{3}{*}{ Haldol } & Baseline & $\begin{array}{r}37.37 \\
0.24\end{array}$ & $\begin{array}{l}2.00 \\
0.39\end{array}$ & $\begin{array}{r}18: 04 \\
0: 07\end{array}$ & $\begin{array}{l}0.47 \\
0.05\end{array}$ & $\begin{array}{r}37.09 \\
0.22\end{array}$ & $\begin{array}{r}36.72 \\
0.18\end{array}$ & $\begin{array}{r}37.75 \\
0.27\end{array}$ & $\begin{array}{r}38.71 \\
0.45\end{array}$ \\
\hline & Week 1 & $\begin{array}{r}37.43 \\
0.27\end{array}$ & $\begin{array}{l}1.84 \\
0.43\end{array}$ & $\begin{array}{r}17: 05 \\
0: 50\end{array}$ & $\begin{array}{l}0.37 \\
0.09\end{array}$ & $\begin{array}{r}37.25 \\
0.21\end{array}$ & $\begin{array}{r}36.89 \\
0.17\end{array}$ & $\begin{array}{r}37.68 \\
0.37\end{array}$ & $\begin{array}{r}38.73 \\
0.43\end{array}$ \\
\hline & Week 2 & $\begin{array}{r}37.35 \\
0.30\end{array}$ & $\begin{array}{l}1.87 \\
0.29\end{array}$ & $\begin{array}{r}17: 20 \\
0: 47\end{array}$ & $\begin{array}{l}0.44 \\
0.06\end{array}$ & $\begin{array}{r}37.13 \\
0.28\end{array}$ & $\begin{array}{r}36.82 \\
0.23\end{array}$ & $\begin{array}{r}37.65 \\
0.31\end{array}$ & $\begin{array}{r}38.69 \\
0.48\end{array}$ \\
\hline \multirow[t]{3}{*}{ Placebo } & Baseline & $\begin{array}{r}37.50 \\
0.22\end{array}$ & $\begin{array}{l}1.77 \\
0.33\end{array}$ & $\begin{array}{r}17: 01 \\
0: 27\end{array}$ & $\begin{array}{l}0.47 \\
0.06\end{array}$ & $\begin{array}{r}37.31 \\
0.23\end{array}$ & $\begin{array}{r}36.93 \\
0.22\end{array}$ & $\begin{array}{r}37.77 \\
0.21\end{array}$ & $\begin{array}{r}38.70 \\
0.46\end{array}$ \\
\hline & Week 1 & $\begin{array}{r}37.54 \\
0.25\end{array}$ & $\begin{array}{l}1.81 \\
0.19\end{array}$ & $\begin{array}{r}16: 55 \\
0: 31\end{array}$ & $\begin{array}{l}0.50 \\
0.04\end{array}$ & $\begin{array}{r}37.34 \\
0.24\end{array}$ & $\begin{array}{r}36.88 \\
0.26\end{array}$ & $\begin{array}{r}37.82 \\
0.28\end{array}$ & $\begin{array}{r}38.69 \\
0.29\end{array}$ \\
\hline & Week 2 & $\begin{array}{r}37.50 \\
0.28\end{array}$ & $\begin{array}{l}2.08 \\
0.09\end{array}$ & $\begin{array}{r}17: 20 \\
0: 46\end{array}$ & $\begin{array}{l}0.46 \\
0.06\end{array}$ & $\begin{array}{r}37.29 \\
0.26\end{array}$ & $\begin{array}{r}36.80 \\
0.24\end{array}$ & $\begin{array}{r}37.80 \\
0.31\end{array}$ & $\begin{array}{r}38.88 \\
0.15\end{array}$ \\
\hline \multicolumn{10}{|c|}{ ANOVA results } \\
\hline $\begin{array}{l}\text { F } \\
d f \\
p<\end{array}$ & & $\begin{array}{c}0.211 \\
4,16 \\
\text { NS }\end{array}$ & $\begin{array}{c}2.296 \\
4,16 \\
\text { NS }\end{array}$ & $\begin{array}{c}2.46 \\
4,16 \\
\text { NS }\end{array}$ & $\begin{array}{c}7.762 \\
4,16 \\
0.01\end{array}$ & $\begin{array}{c}0.761 \\
4,16 \\
\text { NS }\end{array}$ & $\begin{array}{l}1.088 \\
4,16 \\
\text { NS }\end{array}$ & $\begin{array}{c}1.539 \\
4,16 \\
\text { NS }\end{array}$ & $\begin{array}{c}0.594 \\
4,16 \\
\text { NS }\end{array}$ \\
\hline
\end{tabular}

${ }^{\circ \circ} \mathrm{C}$, Mean $\pm \mathrm{SD}$.

${ }^{b} \mathrm{HH}: \mathrm{MM}$, Mean $\pm \mathrm{SD}$.

and haloperidol decreased $\mathrm{T}_{\text {hy }}$ during the light phase, although subchronic treatment diminished the amplitude of $\mathrm{T}_{\text {hy }}$ (Tables 5, 6, and 7).

A novel aspect of these experiments was the use of chronic, noninvasive radio-telemetry techniques to monitor hypothalamic temperature. Handling stress has been shown to strongly influence body temperature (Berkey et al. 1990; Kluger 1991) and to obscure the course of fever in rodents (Kluger 1991). Just as telemetry has been shown to be useful in monitoring fever (Kluger 1991), it also appears to be a valuable method for detecting consistent, but subtle decrements in $T_{b}$ induced by chronic treatment with antidepressant drugs. As a result, an effect of stress on $T_{b}$ should be considered as a possible explanation for the failure of other investigators to detect antidepressant drug effects on $\mathrm{T}_{b}$ (Cranston and Rosendorf 1967; Mogilnicka et al. 1985; Gudelsky et al. 1986; Dilsaver and Alessi 1988; Wozniak et al. 1988). In the future, noninvasive monitoring techniques will probably be essential to identify possible relationships between $T_{h y}$ cooling and mechanisms of antidepressant drugs.

\section{Antidepressant Drug Effects on $T_{\text {hy }}$ Level}

The $T_{\text {hy-lowering effects of antidepressant drugs }}$ reported here are consistent with body temperaturelowering effects of desipramine and clomipramine (Brown and Seggie 1988), lithium (Jensen 1974), and electroconvulsive stimulation (Gleiter et al. 1989) reported in rodents. The fact that the antidepressant drugs used in the current experiments share the common property of altering 5H'T metabolism (Perez-Cruet et al. 1971; Knapp and Mandell 1973; Fuller et al. 1974; Wong et al. 1974; Campbell et al. 1979; Hwang et al. 1980; Mousseau and Greenshaw 1989; Ozaki et al. 1993) implicates this neurotransmitter in the brain-cooling effects of the treatments, although other transmitter systems may be involved. The current experiments extend previous observations of antidepressant-induced lowering of $T_{b}$ to the hypothalamus, the location of a central thermostat that plays a major role in body temperature regulation (Satinoff 1978). As discussed later, because these drugs decrease $T_{\text {hy }}$, activation of colddefense mechanisms should be considered as a possible consequence of chronic drug treatment. 


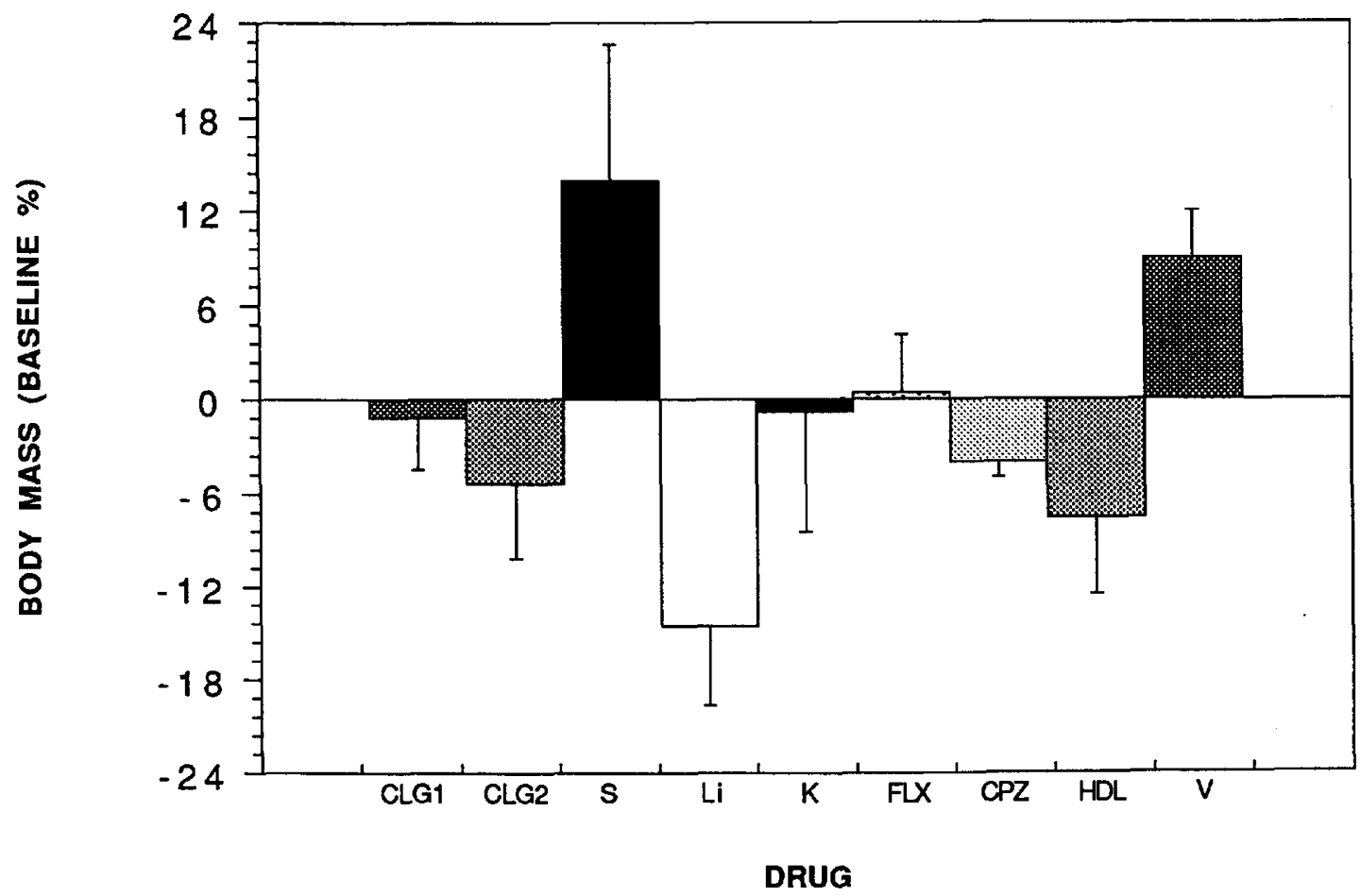

Figure 10. Drug-induced changes in body mass (mean \pm SD) relative to baseline levels are shown for hamsters treated with clorgyline in experiments one and two (CLG1, CLG2), saline control (SAL), lithium (Li), potassium control (K), fluoxetine (FLX), chlorpromazine (CPZ), haloperidol (HDL), and vehicle control (HDLv).

The temperature-decreasing effect of clorgyline on $T_{\text {hy }}$ and $T_{p}$ during the light-(rest-) phase is consistent with our previous experiments in which we measured only $T_{p}$ (Gao et al. 1991). One distinction between the two experimental results, however, is that the lowering of $T_{p}$ (Table 2 ) by clorgyline in the present experiment was greater than in the previous one. In the earlier experiment, tolerance to clorgyline's temperaturedecreasing effects appeared to develop during the second week, perhaps as an artifact of handling stress or the constraint of EEG-monitoring.

Our finding that lithium treatment of hamsters lowered $\mathrm{T}_{\text {hy }}$ is consistent with an earlier report that chronic, clinical doses of dietary lithium decreased rectal temperature in rats (Jensen 1974), but it is inconsistent with reports that prolonged lithium treatment elevates (Tupin 1970; Lund 1987), or does not affect the level of (Campbell et al. 1989) rectal temperature in patients. These discrepancies may be due to differences in the site at which body temperature is monitored. When both temperatures were monitored in the same animal, chronic lithium treatment lowers $T_{p}$ less than $\mathrm{T}_{\text {hy }}$ (Duncan unpublished data). During chronic treatment, $\mathrm{T}_{\text {hy }}$ decreased about $0.13^{\circ} \mathrm{C}$ more than $\mathrm{T}_{\mathrm{p}}$ did.

The results of the fluoxetine experiments confurm our earlier findings that fluoxetine decreases brain temperature (Gao et al. 1992). They further indicate that fluoxetine's effects are not an evoked response to IP drug administration, because fluoxetine was delivered ad lib in the diet. The $\mathrm{T}_{\text {hy-lowering effect of fluoxetine }}$ and food restriction were similar (Table 4). This observation, together with similar observations in foodrestricted birds (Daan et al. 1989; Graf et al. 1989), raises the possibility that the temperature-lowering effect of fluoxetine was related to reduced food intake. Against this interpretation is the fact that a single IP injection of fluoxetine produced an immediate decrease in $\mathrm{T}_{\text {hy }}$ (Gao et al. 1992). Also, based on an earlier finding that food restriction decreases responsiveness to antidepressant drugs (Soubrie 1989), it could be predicted that the temperature-reducing effect of antidepressant drugs would be lessened in food-restricted animals. However, in the previous IP study, the $T_{\text {hy-lowering effect was }}$ greater in chronic than in acute fluoxetine-injected animals. Whether the chronic $\mathrm{T}_{\mathrm{hy}}$-lowering is related to decreased food intake, or to the long half-life of fluoxetine and/or its active metabolites (Fardi et al. 1986; Bergstrom et al. 1988) could be addressed in future experiments. Because both chronic food restriction (Hall et al. 1983) and chronic fluoxetine treatment of rats (Wong and Bymaster 1981; Wong et al. 1985) produce hyposensitivity to serotonergic stimulation; it is possible that diminished serotonergic function may be responsible for the decrease in $\mathrm{T}_{\text {hy }}$ in both cases. 
Table 6. Mean and Repeated Measures Analysis of Variance (ANOVA) Summary of Haldol Decanoate 100 (Haldol, $n=3$ ) and Vehicle $(n=2)$ Effects on Hypothalamic Temperature (Th) during Baseline, Week 2 and Week 3

\begin{tabular}{|c|c|c|c|c|c|c|c|c|c|}
\hline \multirow[b]{2}{*}{ Treatment } & \multirow[b]{2}{*}{ Week } & \multicolumn{4}{|c|}{ 24-Hour } & \multicolumn{2}{|c|}{ Light Phase } & \multicolumn{2}{|c|}{ Dark Phase } \\
\hline & & Th-24 & Range & Acrophase & Amplitude & Th-L & Th-L Min & Th-D & Th-D Max \\
\hline \multirow[t]{3}{*}{ Haldol } & Baseline & $\begin{array}{c}37.46^{a} \\
0.09\end{array}$ & $\begin{array}{l}2.03 \\
0.21\end{array}$ & $\begin{array}{c}17: 55^{b} \\
0: 05\end{array}$ & $\begin{array}{l}0.54 \\
0.05\end{array}$ & $\begin{array}{r}37.11 \\
0.14\end{array}$ & $\begin{array}{c}36.7 \\
0.26\end{array}$ & $\begin{array}{r}37.69 \\
0.09\end{array}$ & $\begin{array}{r}38.73 \\
0.23\end{array}$ \\
\hline & Week 2 & $\begin{array}{r}37.57 \\
0.21\end{array}$ & $\begin{array}{l}1.69 \\
0.23\end{array}$ & $\begin{array}{r}17: 01 \\
0: 12\end{array}$ & $\begin{array}{l}0.31 \\
0.02\end{array}$ & $\begin{array}{r}37.41 \\
0.22\end{array}$ & $\begin{array}{r}37.08 \\
0.19\end{array}$ & $\begin{array}{r}37.66 \\
0.21\end{array}$ & $\begin{array}{r}38.77 \\
0.11\end{array}$ \\
\hline & Week 3 & $\begin{array}{r}37.46 \\
0.21\end{array}$ & $\begin{array}{l}1.76 \\
0.22\end{array}$ & $\begin{array}{r}17: 17 \\
0: 19\end{array}$ & $\begin{array}{l}0.36 \\
0.09\end{array}$ & $\begin{array}{r}37.25 \\
0.25\end{array}$ & $\begin{array}{r}36.89 \\
0.28\end{array}$ & $\begin{array}{r}37.55 \\
0.21\end{array}$ & $\begin{array}{r}38.65 \\
0.10\end{array}$ \\
\hline \multirow[t]{3}{*}{ Vehicle } & Baseline & $\begin{array}{c}37.26 \\
0.2\end{array}$ & $\begin{array}{l}2.09 \\
0.36\end{array}$ & $\begin{array}{r}17: 49 \\
0: 02\end{array}$ & $\begin{array}{l}0.64 \\
0.09\end{array}$ & $\begin{array}{r}36.88 \\
0.32\end{array}$ & $\begin{array}{r}36.42 \\
0.24\end{array}$ & $\begin{array}{r}37.53 \\
0.23\end{array}$ & $\begin{array}{r}38.51 \\
0.12\end{array}$ \\
\hline & Week 2 & $\begin{array}{r}37.18 \\
0.12\end{array}$ & $\begin{array}{l}2.46 \\
0.35\end{array}$ & $\begin{array}{r}17: 52 \\
0: 13\end{array}$ & $\begin{array}{l}0.67 \\
0.08\end{array}$ & $\begin{array}{r}36.73 \\
0.24\end{array}$ & $\begin{array}{r}36.15 \\
0.22\end{array}$ & $\begin{array}{r}37.45 \\
0.15\end{array}$ & $\begin{array}{r}38.60 \\
0.13\end{array}$ \\
\hline & Week 3 & $\begin{array}{c}37.14 \\
0.1\end{array}$ & $\begin{array}{l}2.16 \\
0.58\end{array}$ & $\begin{array}{r}17: 42 \\
0: 40\end{array}$ & $\begin{array}{l}0.64 \\
0.13\end{array}$ & $\begin{array}{r}36.75 \\
0.31\end{array}$ & $\begin{array}{r}36.25 \\
0.28\end{array}$ & $\begin{array}{c}37.40 \\
0.06\end{array}$ & $\begin{array}{r}38.41 \\
0.30\end{array}$ \\
\hline \multicolumn{10}{|c|}{ ANOVA results } \\
\hline $\begin{array}{l}\mathrm{F} \\
d f \\
p<\end{array}$ & & $\begin{array}{c}2.12 \\
2,6 \\
\text { NS }\end{array}$ & $\begin{array}{c}6.08 \\
2,6 \\
\text { NS }\end{array}$ & $\begin{array}{c}3.82 \\
2,6 \\
\text { NS }\end{array}$ & $\begin{array}{c}13.40 \\
2,6 \\
0.05\end{array}$ & $\begin{array}{c}5.96 \\
2,6 \\
0.07\end{array}$ & $\begin{array}{c}8.77 \\
2,6 \\
0.02\end{array}$ & $\begin{array}{c}0.04 \\
2,6 \\
\text { NS }\end{array}$ & $\begin{array}{c}0.16 \\
2,6 \\
\text { NS }\end{array}$ \\
\hline
\end{tabular}

$a{ }^{\circ} \mathrm{C}$, Mean $\pm \mathrm{SD}$.

${ }^{b} \mathrm{HH}: \mathrm{MM}$, Mean \pm SD.

\section{Antidepressant Drug Effects on $T_{\text {hy }}$ Amplitude and Phase}

Both clorgyline and fluoxetine delayed the 24-hour rhythm in $\mathrm{T}_{\text {hy. }}$. Results of a recent experiment have shown that clorgyline also delays the 24-hour pattern of 5 HT levels measured within the suprachiasmatic nucleus (Ozaki et al. 1993). The possibility exists that changes in the timing of daily rhythms of $5 \mathrm{HT}$ and of $\mathrm{T}_{\text {hy }}$ are causally related. Recent experiments have es-

Table 7. Statistical Summary of Antidepressant and Neuroleptic Drug Effects on Hypothalamic Temperature (Thy)

\begin{tabular}{|c|c|c|c|c|c|c|c|c|}
\hline & Thy $_{24}$ & Range & Phase & AMP & ThyL & Thy ${ }_{\text {Lmin }}$ & Thyo & Thy ${ }_{D \max }$ \\
\hline \multicolumn{9}{|l|}{ Antidepressants } \\
\hline Treatment $\times$ week $^{a}$ & 0.001 & $-^{d}$ & 0.001 & - & 0.001 & 0.001 & 0.01 & 0.01 \\
\hline Week $1^{b}$ & 0.015 & - & 0.001 & - & 0.012 & - & 0.014 & - \\
\hline Week $3^{b}$ & - & - & 0.003 & - & 0.046 & - & - & - \\
\hline \multicolumn{9}{|l|}{ LI } \\
\hline Treatment $\times$ week $^{a}$ & 0.016 & - & - & - & 0.01 & 0.035 & - & - \\
\hline Week $6^{b}$ & 0.03 & - & - & - & 0.004 & - & - & - \\
\hline \multicolumn{9}{|l|}{ FLX } \\
\hline Treatment $\times$ week $^{a}$ & & & 0.05 & & & & & \\
\hline Week $^{a}$ & - & 0.018 & & 0.017 & 0.034 & 0.04 & & 0.04 \\
\hline Week 3 & - & $0.02^{c}$ & $0.02^{b}$ & $0.02^{c}$ & $0.05^{c}$ & - & - & $0.051^{c}$ \\
\hline Week 4 & - & - & $0.002^{b}$ & $0.055^{\mathfrak{c}}$ & $0.04^{c}$ & - & - & - \\
\hline \multicolumn{9}{|l|}{$\begin{array}{c}\text { Neuroleptics } \\
\text { CPZ HDL }\end{array}$} \\
\hline Treatment $\times$ week $^{a}$ & - & - & - & 0.01 & - & - & - & - \\
\hline \multicolumn{9}{|l|}{$\mathrm{HDL}_{100}$} \\
\hline Treatment $\times$ week $^{a}$ & - & - & - & 0.05 & - & 0.02 & - & - \\
\hline Week $2^{b}$ & - & - & - & - & - & - & - & - \\
\hline Week $3^{b}$ & - & - & - & 0.04 & - & - & - & - \\
\hline
\end{tabular}

${ }_{b}^{a}$ Repeated Measures ANOVA ( $p$ value equals).

${ }^{b}$ Independent group $t$-test (treatment group versus control group). ( $p$ value equals).

${ }^{c}$ Paired $t$-test (BL versus treatment week). ( $p$ value equals).

$d$ Not significant. 
tablished that 5HT shifts the circadian phase of neuronal activity within the SCN (Prosser et al. 1993). The phase-delaying effect of clorgyline and fluoxetine on the 24-hour rhythms of $\mathrm{T}_{\text {hy }}$ and 5HT may therefore be related to the serotonergic properties of these drugs. Of the three antidepressant drugs tested, lithium alone failed to delay the daily temperature rhythm. Although this observation was unexpected (lithium is well known to delay a number of circadian rhythms outside the SCN (Kripke et al. 1979; McEachron et al. 1982; McEachron et al. 1985), it is consistent with the observation that lithium fails to delay the rhythm of metabolic activity in the SCN (McEachron et al. 1985).

The acrophases of the 24-hour cosine estimated curve-fits of $T_{\text {hy }}$ (Tables $1,3,4,5$, and 6 ) do not closely match the peaks of the 24-hour mean data shown in Figures 7 and 9. For example, in the clorgyline experiment, the peak of mean $\mathrm{T}_{\text {hy }}$ during baseline (BL) occurs at 1530 (Figure 7), whereas the cosine-estimated acrophase occurs at 1731 (Table 1). Masking of the 24hour rhythm in $\mathrm{T}_{\text {hy }}$ by increased wakefulness at the beginning and end of the dark phase (Gao et al. 1991), or increased sleep during the light and mid-dark phases (Gao et al. 1991), is a possible explanation for these apparent phase differences. As shown by the dotted and thin lines in Figures 7 and 9, improved fit of the 24-hour data was obtained by adding the first three harmonics to the fundamental 24-hour cosine curve. An interpretation based on these improved curve-fits, is that masking components are subharmonics of the fundamental 24-hour rhythm.

Fluoxetine was the only antidepressant drug that increased the 24-hour amplitude of $T_{\text {hy }}$. $T_{\text {hy }}$ amplitude diminished during neuroleptic treatment (Tables 5 and 6). This result raises the possibility that diminished amplitude of $\mathrm{T}_{\text {hy }}$ may be an important correlate of neuroleptic drug response, and that different classes of antidepressant drugs may be unique with regard to their phase-delaying or amplitude-increasing effects on the daily pattern of $T_{h y}$.

\section{Neuroleptic Drug Effects on $T_{\text {hy }}$ Level}

In contrast to antidepressant drugs, which produced a sustained decrease in $\mathrm{T}_{\text {hy, }}$, neuroleptic drugs tended to produce an increase in $T_{h y}$, and this increase was transient. The physiological mechanisms responsible for these differences are not known. They may include a variety of processes, including differential effects on neurotransmitter receptor desensitization that accompanies chronic drug treatment, cerebral vasomotor tone, and brain metabolism. The fact that subchronic (3-day) (Andree et al. 1986), or chronic treatment with chlorpromazine (Mikuni and Meltzer 1984; Hong et al. 1988), and chronic treatment with antidepressant drugs (Peroutka and Snyder 1980; Mikuni and Meltzer 1984), decreases the number of $5 \mathrm{HT} 2$ receptors in the rat brain suggests that this receptor is unlikely to account for the differential effects of neuroleptic and antidepressant drugs on $T_{\text {hy. }}$. Because body mass decreased in both the antidepressant and neuroleptic treated animals, the different effects of these drugs on $T_{\text {hy }}$ cannot be explained by their effects on body mass, either.

As reported previously, chlorpromazine produced a decrease in $\mathrm{T}_{\text {hy }}$ during the first 12 hours of treatment (for a review of neuroleptic effects on $\mathrm{T}_{b}$ see Clark and Lipton 1985). Not reported previously, $T_{\text {hy }}$ increased during day 2 and day 3 of chlorpromazine treatment, then returned to baseline. As reported by other investigators, we found that (see Clark and Lipton 1985) haloperidol decanoate 100 had no acute effect on $T_{\text {hy. }}$. However, $T_{\text {hy }}$ subsequently increased during the first 10 days of haloperidol treatment, then returned to baseline levels. These changes were most evident during the diurnal (rest) phase of the 24-hour interval (Figure 8). These different patterns may be related to the different pharmacological profiles of these drugs. Chlorpromazine is an alpha-2 and D1/D2 antagonist, whereas haloperidol is a selective D2 antagonist. Whether repeated injections or implants of these drugs would maintain the elevated $T_{\text {hy }}$ is a question for future research. The rise and fall in $T_{\text {hy }}$ that we observed may have been secondary to corresponding changes that we detected in plasma drug levels. It is also possible that long-term adaptive processes (desensitization) could have been responsible for the time-course of these effects of neuroleptics on $T_{\text {hy }}$. A future experiment could examine whether repeated treatments that maintained elevated plasma drug levels would prolong the elevation in $\mathrm{T}_{\text {hy }}$ that we saw in the acute phase of the experiment.

\section{Relationship Between $T_{\text {hy }}$ and $T_{p}$}

To our knowledge, this is the first experiment in which hypothalamic and peritoneal temperatures were simultaneously and chronically monitored in a freely moving rodent. In earlier experiments in which both temperatures were monitored, animals were restrained by recording wires (Obermeyer et al. 1991), or temperatures were monitored acutely (Ahlers et al. 1991). Our data, which are free of artifacts produced by handling stress (Berkey et al. 1990), showed that, on average, over 24 hours, $T_{\text {hy }}$ was $0.34^{\circ} \mathrm{C}$ higher than $T_{p}$. This finding is consistent with earlier reports that brain temperature is higher than rectal temperature in euthermic mammals (Hayward and Baker 1969; Caputa et al. 1983, 1991; Fuller 1984).

Clorgyline treatment decreased both $T_{h y}$ and $T_{p}$. Relative to baseline measurements however, chronic clorgyline decreased $\mathrm{T}_{\text {hy }} 0.1^{\circ} \mathrm{C}$ more than it decreased $\mathrm{T}_{\mathrm{p}}$, and thereby reduced the temperature difference 
between the hypothalamus and the peritoneal cavity (Figure 3). The smaller decrease in $T_{p}$ relative to $T_{\text {hy }}$ is opposite to the greater conservation of $T_{\text {hy }}$ versus $T_{p}$ observed during behavioral or pharmacological challenge (Taylor and Lyman 1972; Dib and Cabanac 1984; Bejanian et al. 1987; Obermeyer et al. 1991). The biological significance of such a temperature change is unknown. We examined the regression between $T_{\text {hy }}$ and $\mathrm{T}_{\mathrm{p}}$ over 24 hours, but found no evidence of selective hypothalamic cooling at extreme physiological temperatures (Figure 4) as occurs during the thermal stress associated with motor activity (Gordon et al. 1981). In fact, because the decline in $T_{p}$ is less than the decline in $T_{h y}$, it is possible that the relative elevation in $T_{p}$ results from an activation of noncentral cold-defense mechanisms. Recent experiments support a cold-defense interpretation. Clorgyline-treated hamsters (a) self-select ambient temperatures $1^{\circ} \mathrm{C}$ to $2^{\circ} \mathrm{C}$ above control hamsters (Gordon and Duncan 1994), (b) are behaviorally more active than control animals (Duncan et al. 1988; Gordon and Duncan 1994), and (c) have higher plasma corticosteroid levels than control animals (Duncan and Ozaki unpublished data). If a cold-defense response occurs, it cannot have been successful because $T_{p}$ exhibited a net decrease. Whether activation of thermal effector mechanisms by hypothalamic cooling is responsible for the activation of behavior that is induced by these drugs is a question that can be addressed in later experiments. One prediction of this hypothesis is that treatments that prevent hypothalamic cooling would also reverse the activating properties of antidepressant drugs.

\section{Brain Cooling Mechanisms}

Temperature of the mammalian brain is regulated by a combination of factors including regional brain metabolic rate, the temperature of arterial blood supply, the rate of brain blood flow, and heat exchange through the surface and base of the skull (Baker 1982). With regard to metabolism and vascular factors, antidepressant drugs (DMI and phenelzine) decrease glucose utilization (GU) in rats (Gerber et al. 1983), and MAOI (Reinhard et al. 1979) and fluoxetine (Amenta et al. 1985) treatments alter 5HT levels and reuptake within cerebral vessels that regulate brain temperature. In addition, the combination of MAOI and noradrenaline alters cerebral blood flow (Lasbennes et al. 1988). Observations that (a) pharmacological and nonpharmacological manipulations of 5HT decrease brain GU (Grome and Harper 1985; Cudennec et al. 1988), and (b) 5HT is present in brain arterioles (Reinhard et al. 1979; Edvinsson et al. 1983; Scatton et al. 1985) and modulates vasomotor function (Harper and MacKenzie 1977), suggest that this neurotransmitter may be pertinent to drug-induced lowering of $T_{\text {hy }}$.

Evidence suggests that melatonin modulates ther- moregulation in mammals, possibly by affecting cerebral blood flow (Arutyunyan et al. 1964; Shibata et al. 1989; Viswanathan et al. 1990; Cagnacci et al. 1992). Although MAOI treatment increases melatonin levels (Oxenkrug et al. 1985), the present data fail to support the hypothesis that the decrease in $\mathrm{T}_{\text {hy }}$ is melatoninrelated, because pinealectomy failed to reverse clorgy-

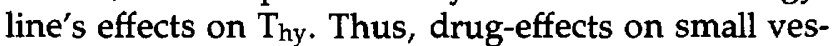
sels and arterioles regulated by $5 \mathrm{HT}$ (Edvinsson et al. 1983), and not drug effects on larger arteries regulated by melatonin (Viswanathan et al. 1990), are the most likely mediators of altered blood flow and hypothalamic cooling.

Because, on the average, the tips of the $T_{\text {hy }}$ probes in the current studies were located about $2000 \mu$ from the ventral surface of the anterior hypothalamus, they may have been affected by venous drainage flowing from the nasal vein into the opthalamic and pterygoid sinuses. In hamsters, cooled venous blood may contribute to the decrease in brain temperature observed during motor activity (Gordon et al. 1981). Because antidepressant drugs alter the density of central alpha and beta adrenergic receptors, and because these receptors regulate blood flow to pools at the base of the brain (Winquist and Bevan 1980; McPherson and Bevan 1987; Kreutzer and Folkow 1988), it is possible that increased venous drainage to the ventral brain surface may have been partly responsible for hypothalamic cooling induced by drugs.

The psychoactive drugs used in these studies alter sleep and food intake, which affect thermoregulation (Berger and Phillips 1988). It is unlikely that the level of food intake was directly related to the different drug effects on $\mathrm{T}_{\text {hy }}$ because drug treatment was associated with decreased levels of food intake in clorgyline, fluoxetine, and haloperidol-treated hamsters (Duncan unpublished data). Also, the relationship between druginduced changes in $T_{\text {hy }}$ and sleep is not clear. Brain temperature tends to increase during REM sleep and decrease during NREM sleep (Parmegiani 1980; Obal et al. 1985), suggesting that drugs which alter sleep might also affect brain temperature. Effects of neuroleptic drugs on sleep have not been studied in hamsters; however, if the change in $\mathrm{T}_{\text {hy }}$ was related to drug effects on sleep, one would predict that in hamsters, neuroleptic, and antidepressant drug treatments would increase and decrease their respective REM-NREM ratios. In contrast, effects of antidepressant drugs on sleep in hamsters have been studied more extensively by our group (Gao et al. 1991, 1992). Clorgyline produces a chronic increase of NREM sleep throughout treatment (Gao et al. 1991) suggesting a possible relationship between drug effects on sleep and body temperature. Although acute and subchronic treatment with fluoxetine (Gao et al. 1992) and clorgyline (Gao et al. 1991) decreases REM sleep and $\mathrm{T}_{\text {hy }}$ in hamsters, prolonged 
fluoxetine treatment decreases $\mathrm{T}_{\text {hy }}$ further, but increases REM sleep (Gao et al. 1992). Overall, the current data do not provide strong support for the possibility that the opposite effects of antidepressant versus neuroleptic drugs on $T_{\text {hy }}$ were related to the drugs' effects on sleep and food intake, but further experiments are warranted to clarify these relationships.

\section{Clinical Relevance}

These are the furst experiments to explore chronic effects of psychoactive drugs on brain temperature in mammals. The facts that clinically relevant drug doses were used in these studies, and that therapeutic plasma neuroleptic (Tang et al. 1984; Simpson and Yadalam 1985; Sramek et al. 1987) and antidepressant drug levels were associated with temperature changes suggest that similar effects may occur in humans; however, there is reason to be cautious in this interpretation. A full range of doses was not used in these studies. It is possible that the different antidepressant versus neuroleptic temperature effects would not be present across the range of doses. Also, the pharmacokinetic properties of these drugs are likely to be affected by species differences, as well as by differences in our methods of drug delivery. These issues can only be answered with further experiments.

As we speculated earlier, drug effects on brain temperature and a resulting cold-defense reaction may contribute to the behavior-activating properties of antidepressant drugs. Recent experiments suggest that the clinical response to sleep deprivation can be modulated by warm and cold ambient temperatures (Wehr 1989), and by the use of antidepressant or neuroleptic drugs (van den Burg et al. 1990). It is possible that the modulating influence of these two treatments on the antidepressant response is related to their common effects on thermoregulatory mechanisms.

During depression, body temperature is often reported to be elevated especially during the rest or sleep phase (Mellerup et al. 1978; Pflug et al. 1981; Avery et al. 1982; Beersma et al. 1983; Lund et al. 1983; van den Hoofdakker and Beersma 1985; Avery et al. 1986; Souetre et al. 1988). Results from recent positron emission tomography scan experiments indicate that overall cerebral glucose metabolism is elevated during NREM sleep in depressed patients versus controls (J.C. Gillin, personal communication 1994). The observation that drugs decrease $T_{\text {hy }}$ during the rest phase indicates their effect may be partly sleep-dependent, and that these drugs may correct a pathological factor (i.e. elevated nocturnal temperature) that is associated with depression. The extent to which drugs exert their therapeutic effects through their effects on temperature regulation could be examined further with animal models of psychopathology (Meerlo et al. 1993; Tornatzky and Miczek 1993).

\section{SUMMARY}

The use of noninvasive radiotelemetry techniques revealed the presence of subtle, but consistent temperature decreases $\left(<0.5^{\circ} \mathrm{C}\right)$ within the hypothalamus during chronic antidepressant drug treatment. Results obtained with these methods suggest that antidepressant drugs, particularly those with serotonergic properties, cool the hypothalamus, whereas neuroleptic drugs have negligible or opposite effects. The fact that drugs with contrasting clinical applications exhibit contrasting thermal properties suggests that the temperature effects might be related to their therapeutic effects. Cooling of hypothalamic tissue during drug treatment may arise from increased arterial blood flow, decreased regional metabolic rate, or increased venous drainage at the base of the hypothalamus. Further experiments will be required to elucidate the contributions of these different factors, and to establish a causal relationship between hypothalamic cooling and antidepressant properties of these drugs.

\section{ACKNOWLEDGMENTS}

Fluoxetine was generously supplied by the Eli Lilly Company. Haloperidol Decanoate 100 was generously supplied by McNeil Pharmaceutical. The authors wish to acknowledge the excellent technical assistance provided by William Orem, Mary Yee, Tracey Waldeck, and Nghia Tang. The authors also wish to thank Dr. C.J. Gordon for his helpful review of the original manuscript.

\section{REFERENCES}

Ahlers ST, Thomas JR, Berkey DL (1991): Hippocampal and body temperature changes in rats during delayed matching-to-sample performance in a cold environment. Physiol Behav 50:1013-1018

Amenta F, De Rossi, M, Mione MC, Geppetti P (1985): Characterization of $(3 \mathrm{H}) 5$-hydroxytryptamine uptake within rat cerebrovascular tree. European J Pharmacol 112:181-186

Andree TH, Mikuni M, Tong CY, Koenig JI, Meltzer HY (1986): Differential effect of subchronic treatment with various neuroleptic agents on serotonin-2 receptors in rat cerebral cortex. J Neurochem 46:191-197

Arutyunyan GS, Mashkovski MD, Roschina LF (1964): Pharmacological properties of melatonin. Federation Proc Trans (Suppl 23):T1330-1332

Avery DH, Wildschiodtz G, Rafaelsen OJ (1982): Nocturnal temperature in affective disorder. J Affective Disord 4:61-71

Avery DH, Wildschiodtz G, Smallwood RG, Martin D, Rafael- 
sen OJ (1986): REM latency and core temperature relationships in primary depression. Acta Psychiatr Scand 74:269-280

Baker MA (1982): Brain cooling in endotherms in heat and exercise. Ann Rev Physiol 44:85-96

Beersma DGM, van den Hoofdakker RH, van Berkestijn HWBM (1983): Circadian rhythms in affective disorders. Body temperature and sleep physiology in endogenous depressives. Advances Biological Psychiat 11:114-127

Bejanian M, Finn DA, Syapin PJ, Alkana RI (1987): Rectal and brain temperatures in ethanol intoxicated mice. Psychopharmacology 92:301-307

Berger RJ, Phillips NH (1988): Comparative aspects of energy metabolism. Acta Physiol Scand Suppl 574:21-27

Bergstrom RF, Lemberger L, Farid NA, Wolen RL (1988): Clinical pharmacology and pharmacokinetics of fluoxetine: A review. Br J Psychiatry 153(suppl 3):47-50

Berkey DL, Meeuwsen KW, Barney CC (1990): Measurements of core temperature in spontaneously hypertensive rats by radiotelemetry. Am J Physiol 258:R743-R749

Brown GM, Seggie J (1988): Effects of antidepressants on entrainment of circadian rhythms. Progress Neuropsychopharmacol Biol Psychiatry 12:299-306

Cagnacci A, Elliott JA, Yen SSC (1992): Melatonin: A major regulator of the circadian rhythm of core temperature in humans. J Clin Endocrinol Metab 75:447-452

Campbell IC, Robinson DS, Lovenberg W, Murphy DL (1979): The effects of chronic regimens of clorgyline and pargyline on monoamine metabolism in the rat brain. J Neurochem 32:49-55

Campbell SS, Gillin JC, Kripke DF, Janowsky DS, Risch SC (1989): Lithium delays circadian phase of temperature and REM sleep in a bipolar depressive: A case report. Psychiatry Res 27:23-29

Caputa M, Kadziela W, Narebski J (1983): Cerebral temperature regulation in resting and running guinea-pigs (Cavia porcellus). J Therm Biol 8:265-272

Caputa M, Kamari A, Wachulec M(1991): Selective brain cooling in rats resting in heat and during exercise. J Therm Biol 16:19-24

Clark WG, Clark YL (1980): Changes in body temperature after administration of adrenergic and serotonergic agents and related drugs including antidepressants. Neurosci Biobeh Rev 4:281-375

Clark WG, Lipton JM (1985): Changes in body temperature after administration of amino acids, peptides, dopamine, neuroleptics, and related agents: II. Neurosci Biobeh Rev 9:299-371

Clark WG, Lipton JM (1986): Changes in body temperature after administration of adrenergic and serotonergic agents and related drugs including antidepressants: II. Neurosci Biobehav Rev 10:153-220

Cranston WI, Rosendorf C (1967): Central temperature regulation in the conscious rabbit after monoamine oxidase inhibition. J Physiol 193:359-373

Cudennec A, Duverger D, Serrano A, Scatton B, MacKenzie ET (1988): Influence of ascending serotonergic pathways on glucose use in the conscious rat brain. II. Effects of electrical stimulation of the rostral raphe nuclei. Brain Res 444:227-246

Daan S, Masman D, Strijkstra A, Verhulst S (1989): Intraspecific allometry of basal metabolic rate: Relations with body size, temperature, composition, and circadian phase in the Kestral, Falco Tinnunculus. J Biol Rhythms $4: 267-283$

Dib B, Cabanac M (1984): Skin or hypothalamic cooling: A behavioral choice by rats. Brain Res 302:1-7

Dietzel M, Saleto B, Lesch OM, Sieghart W, Schjerve M(1986): Light treatment in depressive illness. Eur Neurol 25 (Suppl 2):93-103

Dilsaver SC, Alessi NE (1988): Temperature as a dependent variable in the study of cholinergic mechanisms. Prog Neuropsychopharmacol Biol Psychiatry 12:1-32

Duncan WC, Gao B, Wehr TA (1990): Light and antidepressant drugs: Interactions with vigilance states, body temperature, and oxygen consumption in Syrian hamsters. Edited by Jorne J. Sleep ‘90, Bochum, Pontenagel Press, pp 356-359

Duncan WC, Tamarkin L, Sokolove PG, Wehr TA (1988): Chronic clorgyline treatment of Syrian hamsters: An analysis of effects on the circadian pacemaker. J Biol Rhythms 3:305-322

Edvinsson L, Degueurce A, Duverger D, MacKenzie ET, Scatton B (1983): Central serotonergic nerves project to the pial vessels of the brain. Nature 306:55-57

Elsenga S, van den Hoofdakker RH (1988): Body core temperature and depression during total sleep deprivation in depressives. Biol Psychiatry 24:531-540

Farid NA, Bergstrom RF, Lemberger L, Ziege EA, Tenbarge J, Wolen RL, Dhahir P (1986): Studies on the disposition of fluoxetine and radioactive isotopes. 15th CINP Congress, Puerto Rico, Collegium Internationale Neuropsychopharmacologium

Fernstrom MH, Epstein LH, Spiker DG, Kupfer DJ (1985): Resting metabolic rate is reduced in patients treated with antidepressants. Biol Psychiatry 20:688-692

Fuller CA (1984): Circadian brain and body temperature rhythms in the squirrel monkey. Am J Physiol 246: R242-R246

Fuller RW, Perry KW, Molloy BB (1974): Effect of an uptake inhibitor on serotonin metabolism in rat brain: Studies with 3-(p-trifluoromethylphenoxy)-n-methyl-3-phenylpropylamine (Lilly 110140). Life Sci 15:1161-1171

Gaist PA, Obarzanek E, Skwerer RG, Duncan CC, Shultz PM, Rosenthal NE (1990): Effects of bright light on resting metabolic rate in patients with seasonal affective disorder and control subjects. Biol Psychiatry 28:989-996

Gao B, Duncan WC Jr., Wehr TA (1991): Clorgyline-induced reduction in body temperature and its relationship to vigilance states in Syrian hamsters. Neuropsychopharmacology 4:187-197

Gao B, Duncan WC Jr., Wehr TA (1992): Fluoxetine decreases brain temperature and REM sleep and Syrian hamsters. Psychopharmacology 106:321-329

Gerber JC, Choki J, Brunswick DJ, Reivich M, Frazer A (1983): The effect of antidepressant drugs on regional cerebral glucose utilization in the rat. Brain Res 269:319-325 
Gleiter CH, Costello MJ, Nutt DJ (1989): Effect of single and repeated electroconvulsive shock on body temperature in mice. Convulsive Therapy 5:152-156

Goetze U, Tolle R (1987): Circadian rhythms of free urinary cortisol, temperature and heart rate in endogenous depressives and under antidepressant therapy. Neuropsychobiology 18:175-184

Gordon CJ, Duncan WC (1994): Autonomic and behavioral thermoregulation in the golden hamster during subchronic administration of clorgyline. Pharm Biochem Behav 48:119-125

Gordon CJ, Resvani AH, Fruin ME, Trautwein S, Heath JE (1981): Rapid brain cooling in the free-running hamster Mesocricetus auratus. J Appl Physiol 51:1349-1354

Graf R, Krishna S, Heller HC (1989): Regulated nocturnal hypothermia induced in pigeons by food deprivation. Am J Physiol 256:R733-R738

Grome JJ, Harper AM (1985): Serotonin depression of local cerebral glucose utilization after monoamine oxidase inhibition. J Cereb Blood Flow Metabol 5:473-475

Gudelsky GA, Koenig JL, Jackman H, Meltzer HY (1986): Suppression of the hypo- and hyperthermic responses to $5 \mathrm{HT}$ agonists following the repeated administration of monoamine oxidase inhibitors. Psychopharmacology 90: 403-407

Hall RD, Leahy JP, Robertson WM (1983): Hyposensitivity to serotonergic stimulation in protein malnourished rats. Physiol Behav 31:187-195

Harper M, MacKenzie ET (1977): Effects of 5-hydroxytryptamine on pial arteriole calibre in anesthetized cats. J Physiol 271:735-746

Hayward JN, Baker AN (1969): A comparative study of the role of the cerebral arterial blood in the regulation of brain temperature in five mammals. Brain Res 16:417-440

Hong M, Roots EJ, Jenner P, Marsden CD (1988): The effect of long-term treatment with amine-depleting drugs or chlorpromazine on alpha-adrenoreceptors and 5-HT2 receptors in the brain of the rat. Neuropharmacology 27:519-527

Hwang EC, Magnussen I, Van Woert MH (1980): Effects of chronic fluoxetine administration on serotonin metabolism. Res Commun Chem Pathol Pharmacol 29:79-98

Jensen J (1974): The effect of prolonged lithium ingestion on morphine actions in the rat. Acta Pharmacol et Toxicol 35:395-402

Kay DC, Blackburn AB, Buckingham JA, Karacan I (1976): Human pharmacology of sleep. In Williams RL, Karacan I (eds), Pharmacology of Sleep. New York, John Wiley and Sons, pp 83-210

Kluger MJ (1991): Fever: Role of pyrogens and cryogens. Physiol Rev 71:93-127

Knapp S, Mandell AJ (1973): Short- and long-term lithium administration: Effects on the brains serotonergic biosynthetic systems. Science 180:645-647

Kreutzer H, Folkow LP (1988): Vascular control of brain cooling in reindeer. Am J Physiol 254:R730-R739

Kripke DL, Judd LL, Hubbard DS, Janowsky DS, Huey LY
(1979): The effect of lithium carbonate on the circadian rhythm of sleep in human subjects. Biol Psychol 14:545-548

Lasbennes F, Lacombe P, Seylaz J (1988): Effect of monoamine oxidase inhibition on the regional cerebral blood flow response to circulating noradrenaline. Brain Res 454:205-211

Lund R (1987): Body temperature and efficacy of antidepressant drugs. Sleep Res 16:104

Lund R, Kammerloher A, Dirlich G (1983): Body temperature in endogenously depressed patients during depression and remission. In Goodwin FK, Wehy TA (eds), Circadian Rhythms and Psychiatry, Pacific Grove, CA, Boxwood Press

McEachron DL, Kripke DF, Sharp FR, Lewy AJ, McClellan DE (1985) Lithium effects on selected circadian rhythms in rats. Brain Res Bull 15:347-350

McEachron DL, Kripke DL, Hawkins R, Haus E, Pavlinac D, Deftos L (1982): Lithium delays biochemical rhythms in rats. Neuropsychobiology 8:12-29

McPherson GA, Bevan JA (1987): Specialization in beta-1 and beta- 2 adrenoceptor distribution in veins of the rabbit face: Relationship to myogenic tone and sympathetic nerve innervation. J Pharm Exp Ther 240:99-105

Meerlo P, Vos J, Wiersma A, De Boer SF, Koolhaas JM, Daan S, Van den Hoofdakker RH (1993): Chronobiological consequences of social stress in rats. Neuropsychopharmacology 9:165S-166S

Mellerup ET, Widding A, Wildschiodtz G, Rafaelson OJ (1978): Lithium effect on temperature rhythm in psychiatric patients. Acta Pharmacol Toxicol 42:125-129

Mikuni M, Meltzer H (1984): Reduction of serotonin-2 receptors in rat cerebral cortex after subchronic administration of imipramine, chlorpromazine, and the combination thereof. Life Sciences 34:87-92

Mogilnicka E, Klimek V, Nowak G, Czyrak A (1985): Adaptive and differential changes on B- and A2-adrenoreceptors mediated hyperthermia after chronic treatment with antidepressant drugs in the rat kept at high ambient temperature. J Neural Transm 63:237-246

Mousseau DD, Greenshaw AJ (1989): Chronic effects of clomipramine and clorgyline on regional levels of brain amines and acid metabolites in rats. J Neural Trans [Gen Sect] 75:73-79

Obal F Jr, Rubicsek G, Alfoldi P, Sary G, Obal F (1985): Changes in the brain and core temperatures in relation to various arousal states in rats in the light and dark periods of the day. Pflugers Arch 404:73-79

Obermeyer W, Bergmann BM, Rechtschaffen A (1991): Sleep deprivation in the rat: XIV. Comparison of waking hypothalamic and peritoneal temperatures. Sleep 14: 285-293

Oxenkrug GF, McCauley R, McIntyre IM, Filipowicz C (1985): Selective inhibition of MAO-A but not MAO-B activity increases rat pineal melatonin. J Neural Transm 61: 265-270

Ozaki N, Duncan WC, Johnson KA, Wehr TA (1993): Diurnal variations of serotonin and dopamine levels in discrete brain regions of Syrian hamsters and their modification by chronic clorgyline treatment. Brain Res 627:41-48

Parmeggianni PL (1980): Temperature regulation during sleep: 
A study in homeostasis. In Orem J, Barnes CD (eds), Physiology in Sleep (Research Topics in Physiology). New York, Academic Press, pp 97-143

Perez-Cruet J, Tagliamonte A, Tagliamonte P, Gessa GL (1971): Stimulation of serotonin synthesis by lithium. J Pharm Exp Therap 178:325-330

Peroutka SJ, Snyder S (1980): Long-term antidepressant treatment decreases spiroperidol-labeled serotonin receptor binding. Science 210:88-90

Pflug B, Johnsson A, Ekse AT (1981): Manic depressive states and daily temperature. Acta Psychiat Scand 63:277-289

Prosser R, Dean RR, Edgar DM, Heller HC, Miller JD (1993): Serotonin and the mammalian circadian system: In vitro phase shifts by serotonergic agonists and antagonists. J Biol Rhythms 8:1-16

Reinhard JF Jr., Liebmann JE, Schlosberg AJ, Moskowitz MA (1979): Serotonin neurons project to small blood vessels in the brain. Science 206:85-87

Rosenthal NE, Levendosky AA, Skwerer RG, JosephVanderpool JR, Kelly KA, Hardin T, Kasper S, DellaBella P, Wehr TA (1990): Effects of light-treatment on core body temperature in seasonal affective disorder. Biol Psychiatry 27:39-50

Satinoff E (1978): Neural organization and evolution of thermal regulation in mammals. Science 201:16-22

Scatton B, Duverger D, L'Heureux R, Serrano A, Fage D, Nowicki J, MacKenzie ET (1985): Neurochemical studies on the existence, origin, and characteristics of the serotonergic innervation of small pial vessels. Brain Res 345:219-229

Schulz H, Lund R (1983): Sleep onset REM episodes are associated with circadian parameters of body temperature. Biol Psychiatr 18:1411-1426

Shibata S, Satake N, Takagi T, Usui H (1989): Vasorelaxing action of melatonin in rabbit basilar artery. Gen Pharmac 20:677-680

Simpson GM, Yadalam S (1985): Blood levels of neuroleptics: State of the art. J Clin Psychiatry 46(Sec 2):22-28

Soubrie P, Martin P, Massol J, Gaudel G (1989): Attenuation of response to antidepressants in animals induced by reduction in food intake. Psychiatry Research 27:149-159

Souetre E, Salvati E, Wehr TA, Sack DA, Krebs B, Darcourt $G$ (1988): Twenty-four hour profiles of body temperature and plasma TSH in bipolar patients during depression and during remission and in normal control subjects. Am J Psychiatry 145:1133-1137

Sramek J, Herrera J, Roy S, Parent M, Hudgins R, Costa J, Alatorre E (1987): An analysis of steady state chlorpromazine plasma levels in the clinical setting. J Clin Psychopharmacol 7:117-118
Tang SW, Glaister J, Davidson L, Toth R, Jeffries JJ, Seeman P (1984): Total and free plasma neuroleptic levels in schizophrenic patients. Psychiatry Res 13:285-293

Taylor CR, Lyman CP (1972): Heat storage in running antelope: Independence of brain and body temperature. Am J Physiol 222:114-117

Teicher M, Barmer NI (1990): COSIFIT: An interactive program for simultaneous multioscillator cosinor analysis for time series data. Comput Biomed Res 23:283-295

Tornatzky W, Miczek KA (1993): Long-term impairment of autonomic circadian rhythms after brief intermittent social stress. Physiol Behav 53:983-993

Tupin JP (1970): Certain circadian rhythms in manic-depressives and their response to lithium. Int Pharmacopsychiat 227-232

van den Burg W, Bouhuys AL, van den Hoofdakker $R H$, Beersma DGM (1990): Sleep deprivation in bright and dim light: antidepressant effects on major depressive disorder. J Affective Disord 19:109-117

van den Hoofdakker R, Beersma D (1985): On the explanation of short REM latencies in depression. Psychiatr Res $16: 155-163$

Viswanathan M, Laitinen JT, Saavedra JM (1990): Expression of melatonin receptors in arteries involved in thermoregulation. Proc Natl Acad Sci USA 87:6200-6203

Wehr TA (1989): Sleep loss: A preventable cause of mania and other excited states. J Clin Psychiatry 50:8-16

Winquist RJ, Bevan JA (1980): Temperature sensitivity of tone in the rabbit facial vein: Myogenic mechanism for cranial thermoregulation. Science 207:1001-1002

Wong DT, Bymaster FP (1981): Subsensitivity of serotonin receptors after long-term treatment of rats with fluoxetine. Comm Chem Path Pharmacol 32:41-51

Wong DT, Horng JS, Bymaster FP, Hauser KL, Molloy BB (1974): A selective inhibitor of serotonin uptake: Lilly 110140, 3-(p-trifluoromethylphenoxy)-n-methyl-3-phenylpropylamine. Life Sci 15:471-479

Wong DT, Reid LR, Bymaster FP, Threlkeld PG (1985): Chronic effects of fluoxetine, a selective inhibitor of serotonin uptake, on neurotransmitter receptors. J Neural Transm 64:251-269

Wozniak KM, Aulakh CS, Hill JL, Murphy DL (1988): The effect of 8-OH-DPAT on temperature in the rat and its modification by chronic antidepressant treatments. Pharmacol Biochem Behav 30:451-456

Wu JC, Gillin JC, Buchsbaum MS, Hershey T, Hazlett E, Sicotte N, Bunney WE (1991): The effect of sleep deprivation on cerebral glucose metabolic rate in normal humans assessed with positron emission tomography. Sleep $14: 155-162$ 